\title{
Terhelő örökség. Az iráni gazdaság lehetőségei és kihívásai a 2021-es elnökválasztás után
}

\author{
A Burdensome Legacy. Opportunities and Challenges \\ for the Iranian Economy After the 2021 Presidential Election
}

Fórián-Szabó Viktor és Kovács Tamás

https://oi.org/10.47707/Kulugyi Szemle.2021.3.2

Összefoglaló: Irán a 2021-es elnökválasztás után az 1979-es iszlám forradalom óta az egyik legnagyobb kihívással néz szembe. A gazdasági szankciók, a küszöbön álló vízválság és a világjárvány komolyan próbára teszik a fejlődő ország gazdaságát. A jelenlegi válságok kezeléséhez döntő fontosságú lesz, hogy Teherán hogyan helyettesíti az olajjövedelmet stabilabb bevétellel, és hogyan teszi hatékonyabbá a gazdaságát. E kérdések tekintetében elemeztük a 2008-ban megkezdett iráni privatizációs folyamatnak a gazdasági szektorok ra vonatkozó hatásait. Arra a következtetésre jutottunk, hogy összességében a reformok szüikségesek és eredményesek voltak, mivel növelték az állami jövedelmet, jelentősen hozzájárultak a gazdaság bővüléséhez, és csökkentették az országnak az olajtól való fiskális függőségét. A reformokat azonban találomra hajtották végre, a külföldről másolt politikákat úgy alkalmazták, hogy a döntés hozók nem vették figyelembe Irán gazdasági és társadalmi valóságát. Ezért a reformok többé-kevésbé „félúton” megragadtak.

Kulcsszavak: Irán, olajfüggőség, ágazati elemzés, reformok

Abstract: After the presidential election of 2021, Iran faces one of its greatest challenges since the 1979 Islamic Revolution. Economic sanctions, an imminent water crisis and a global pandemic seriously test the developing country's economy. To cope with the current set of crises, it will be crucial how the country will replace oil income with more slable revenue and how it will make il's economy more effective. In this regard, we have analysed Iran's privatisation process commenced in 2008, and its effects on Iran's economic sectors. We have concluded that, overall, the reforms were necessary and fruitful, as they increased state income, significantly contributed to economic growth and reduced the country's fiscal dependence on oil. However, the reforms were carried out haphazardly, policies were implemented from abroad 


\section{Külïgyi Szemle}

and policymakers didnt lake the country's economic and societal reality into account. Therefore the reforms have more or less stuck "half-way".

Keywords: Iran, oil dependence, sectoral analysis, reforms

\section{Bevezetés}

Irán a világ egyik legősibb civilizációja, több mint 2500 éves múlt ra tekint vissza. Gazdag kultúrája és öröksége ellenére azonban csak az 1960-as években kezdte meg a korszerúsítést. ${ }^{1}$ Addig a megfelelő intézményi keret is hiányzott (pl. a banki és biztosítási rendszeren belül), és Mohammad Reza Pahlavi sah azokat Nyugatról, küilönösen Franciaországból kívánta importálni. ${ }^{2}$ Az 1960-as és 1970-es évekbeli eróltetett modernizációs terv - más néven: a „fehér forradalom” - a lakosság egy részének az ellenszenvét váltotta ki, és a tüntetések az iráni iszlám forradalomhoz vezettek - amelynek a jelentősége a mai napig heves viták tárgya. Az 1979-es hatalomátvétel szembeállította az országot a Nyugattal, és Irán egy különálló gazdasági utat igyekezett követni, amely az iszlám társadalmi igazságosság doktrínáját vette alapul, és a még abban az évben elfogadott, majd 1989-ben módosított alkotmányba is belekerült (Eslam.de, 2006).

A szakirodalom elsősorban az 1979-es forradalom utáni korszak „iszlám” jellegére összpontosít, gyakran szembeállítva a régi rezsimet az új berendezkedéssel, s kevesebb figyelem irányul az olyan, eddig megválaszolatlan kérdésekre, hogy például hogyan lehetne megszüntetni az Irán és az iparosodott világ közötti, leküzdhetetlennek túnő

1 Gazdasági szempontból előtte igencsak fejletlen volt az ország, lásd Hans Bobek osztrák földrajztudós 1967-ben íródott átfogó tanulmányát (Bobek, 1967). Ennek oka az volt, hogy bár az ország nyersanyagkincseinek a kiaknázása már a 20. század elején megkezdődött, az állam az 1950-es évekig nem, illetve csak csekély mértékben részesedett azok bevételeiből (Abrahamian, 2018, 127. o.).

2 Ilyen volt például a törvényi keretrendszer - amely szinte kivétel nélkül olyan francia mintákon alapszik, mint az 1929-től kezdődően, több lépcsőben elfogadott Polgári törvénykönyv vagy a Kereskedelmi törvénykönyv (1932) -, illetve, mint arról később e tanulmányban szó lesz, a pénzügyi szervezetek felüigyeleti keretrendszere, amit az 1960-as évek végétől kodifikáltak. 
fejlődési szakadékot, és hogy miért nem lett az ország az iszlám Ja pán. (Sharifi, 2014).

Az iráni vezetés 2005-ben egy kormányzati ciklusokon átívelő, húszéves nemzeti célkitűzést fogalmazott meg, amely szerint a fejlődési időszak végéig hazájuk „fejlett országgá válik, és a régióban első helyen lesz a gazdaság, a tudás és a technológia terén" (Khameni, 2005). Már csak négy és fél év maradt ennek az időszaknak a végéig, és Irán igencsak távol van a kívánt céltól.

A 2021-es elnökválasztás óta - a virágzó gazdaság helyett - a Trump-adminisztráció által visszaállított szankciók (Csicsmann, 2021), a történelmileg alacsony olajárak, a globális koronavírus-jár vány, valamint a küszöbön álló vízkrízis (Szálkai és Szabó, 2021) következtében Irán valószínúleg az öbölháború óta az egyik legnagyobb kihívással küzd. Az ország látszólagos és látens gazdasági képességei határozzák meg, hogy túljut-e a jelenlegi válsághalmazon, és ha igen, milyen módon (Iszlámi, 2019).

A tanulmányunkban megpróbálunk egy pillanatképet adni Irán gazdaságának jelenlegi állapotáról. A szakirodalom feldolgozásánál túlnyomórészt iráni forrásokra támaszkodtunk, a statisztikáknál igyekeztünk a legfrissebb adatokat begyűjteni, ám néhány esetben nem állt rendelkezésüinkre a folyó naptári évre ${ }^{3}$ vonatkozó információ, de akkor is megpróbáltunk a legfrissebb tényekre támaszkodni.

A tanulmány elsôdleges fókuszát az iráni túlterhelt közszféra liberalizációs és deregulációs folyamata jelenti. A közszféra csökkentésének a kérdése a világ közgazdászai körében - különösen a washingtoni konszenzus ${ }^{4}$ fényében - mindig visszatérő téma (Fukuvama, 2004. 5. o.), és fölöttébb igaz ez a Közel-Kelet legtöbb,

3 Az iráni statisztikák az iráni naptári évet veszik alapul, így a folyó év március 21 étől a következő év március 20-ig tart.

4 A washingtoni konszenzus egy, a Világbank és az IMF által támogatott, 10 pontban megfogalmazott 1989-es eszközcsomag, amely többek között a gazdaság globális deregulációját és a gazdaságban játszott állami szerep csökkentését tartalmazta. Az eredeti formájában Latin-Amerika problémái álltak a fókuszban, de később a különböző iskolák és pénzügyi szervezetek révén külön életet kezdett el élni, és ma már sokféle kontextusban használják. Az utóhatásai erősen vitatottak, a vele kapcsolatos gazdasági doktrínát gyakran „neoliberalizmusnak” is nevezik. 


\section{Külïgyi Szemle}

nyersanyagokon alapuló gazdaságával kapcsolatban. ${ }^{5}$ Ugyanakkor e helyen röviden megjegyezzük, hogy az elmúlt évtizedben éppen a nyugati demokráciák azok, amelyek kiemelték annak a kockázatát, hogy túlságosan támaszkodnak a piacvezérelt globalizációra, és a globális pénzügyek nagyobb szabályozását szorgalmazták (Birdsall, Fukuyama, 2011), továbbá az IMF és a Világbank 2021 tavaszi ülésein sem az állami kiadások visszafogása lett a legfőbb tanulság: szüikség lehet az állami beruházások növelésére, erősíteni kell a digitalizációt és a zöldgazdaságot érintő fejlesztéseket. Mindenesetre az iráni program bejelentése óta 16 év telt el, így mára látható, hogy ez a politika a gazdaság egészére hatást gyakorolt.

\section{Gazdasági áttekintés}

Egyes gazdasági mutatók, ágazati teljesímények és a regionális összehasonlíás

Először néhány statisztikát kívánunk ismertetni az iráni gazdaság általános szerkezetéról. A következő diagramok a gazdaságnak az 1338 és 1393-as naptári évek közötti ${ }^{6}$ fejlődését mutatják be, valamint annak a szénhidrogén-erőforrásoktól való függőségét. Továbbá a közve tett adók (pl. áfa, vámok) alakulása és az ország kereskedelmi mérlege is látható az ábrán.

Az első két diagramról könnyen leolvasható, hogy az ötvenes évek ben részlegesen államosított olajszektor a következő évtizedekben jelentősen hozzájárult az iráni GDP-hez, és a hetvenes évek közepére már az ország bruttó hazai termékének a felét adta. Az ábrákon látszik, hogy a 1979-es forradalom és az Amerikai Egyesült Államok által kiszabott szankciók megszakították az ország gazdasági fejlődését. Míg addig annak szerkezete egy tipikus járadékos gazdaságra emlékeztetett - hagyományosan magas kereskedelmi hiánnyal és

5 Példaként lehetne említeni Szaúd-Arábia Vision 2030 programját, az Egyesült Arab Emírségek liberalizációs politikáját, de az iszlám világ többi államában (pl. Üzbegisztánban) is megfigyelhető ez a tendencia.

6 Ez a mi naptárunk szerint az 1959. március 22. és 2015. március 20. közötti időszakot jelenti. 
rendkívüili jelentőségû szénhidrogén-ágazattal -, a helyzet 1979 után megváltozott. Az ország gazdasági fejlődését már nem annyira az olajszektor húzta, hanem - mint az a 2. ábrán is látható - más ágazatok, főleg a szolgáltatások. Mivel Irán a hetvenes évekig kezdetleges ipari kapacitásokkal rendelkezett, jelentős mértékben küllföldi behozatalra szorult, és ez látszott az évtized elejéig egyre növekvő külkereskedelmi hiányán is. A forradalom után és az iraki-iráni háború (19801988) alatt a gazdaság stagnálással és visszaeséssel küzdött ugyan, de az látszólag kevéssé érintette a produktív ágazatokat, 1990-ben pedig lassú fellendülési fázis vette kezdetét, amelyben nem az olajszektor volt a gazdaság elsődleges húzóágazata. A hozzáadottérték-adó (héa) ${ }^{7}$ 2008-as bevezetése (International Labour Organization, 2008) eredményeként pedig lassan elkezdtek emelkedni az ország adóbevételei is, és a költségvetésnek már rendelkezésére állnak az olajnál sokkal kiszámíthatóbb bevételek is.

1. ábra ${ }^{8}$

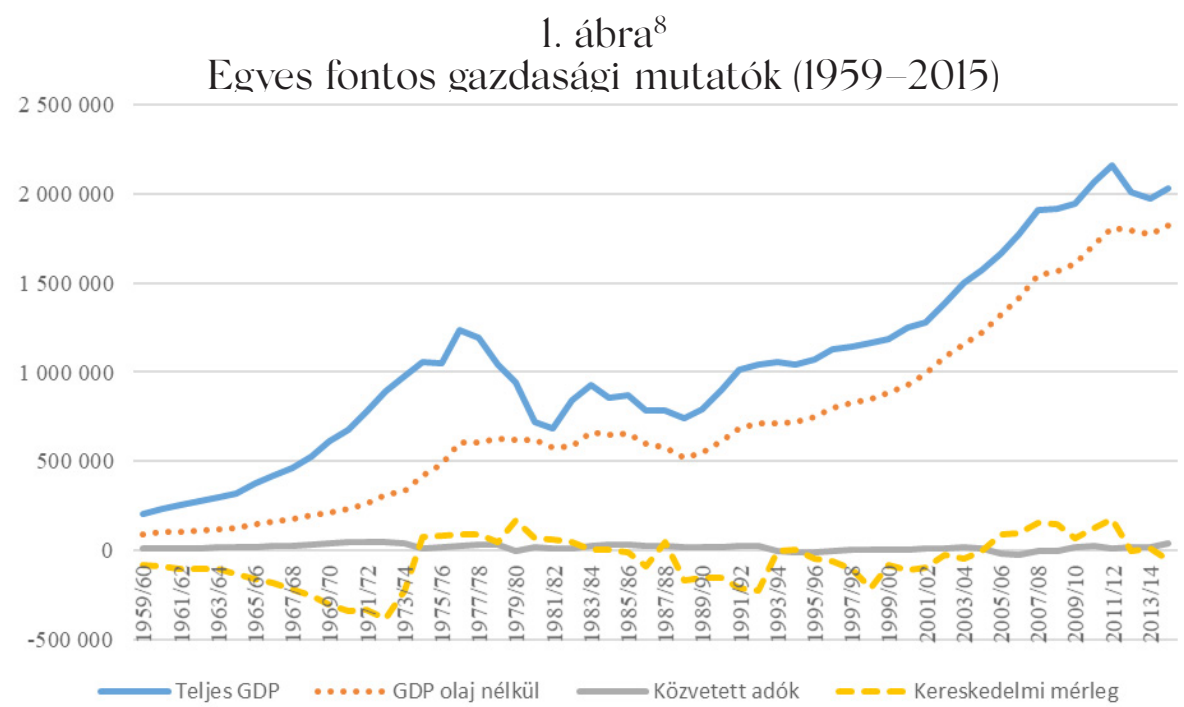

Megjegyzés: Az árak az 1383-as iráni naptári évi (2004. március 20.-2005. március 20.) szinten, milliárd iráni riálban értendőek.

7 Ami Magyarországon megfelel az általános forgalmi adó (áfa) fogalmának, és a köznyelvben is inkább ez a fogalom honosult meg.

8 Forrás: Central Bank of the Islamic Republic of Iran, 2020 b. 


\section{Külïgyi Szemle}

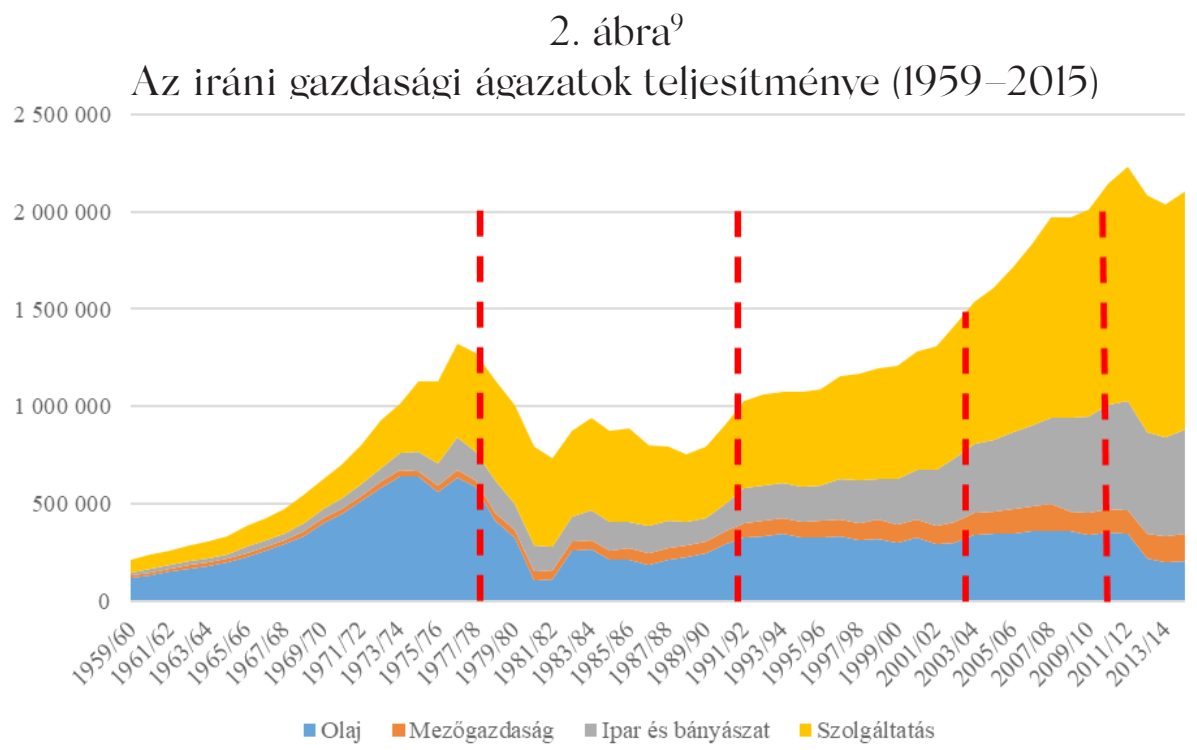

Megjegyzés: Az árak az 1383-as iráni naptári évi (2004. március 20.-2005. március 20.) szinten, milliárd iráni riálban értendőek.

Az ábrák alapján megállapíthatjuk, hogy az elmúlt 60 évben az iráni gazdaság teljes körű átalakuláson ment keresztüil. Míg 1960-ban a szénhidrogén-ágazat a GDP 56 százalékát adta, addig ez az arány 2014-ben már csak 10 százalék volt. A mezőgazdaság a vizsgált időszakban abszolút értékben jelentős bőviulésen ment keresztül, de az összgazdaságon belüli 7-8 százalékos aránya nagyjából ugyanazon a szinten maradt, mint a forradalom előtt. Viszonylagosan az ipari és bányászati termelés nőtt a legnagyobb mértékben: 1960-ban a GDP 7 , 1979-ben 13, 2015-ben pedig már 26 százalékát adta. 1960-ban a szolgáltatásokból származott a gazdasági termelés mintegy 30, 2015-ben pedig már a 60 százaléka. Abszolút számokban a kibocsátás viszont majdnem a hússzorosára nőtt.

Ezen a ponton érdemes egy pillantást vetni a Perzsa-öböl túloldalán fekvő, szintén olajexportőr Szaúd-Arábia és az Egyesüilt Arab Emírségek gazdaságának a szerkezetére. Szaúd-Arábiában a gazdaság diverzifikálása érdekében a közelmúltban tett erőfeszítések (Vision

9 Forrás: Central Bank of the Islamic Republic of Iran, 2020b. 
2030) ellenére az olaj továbbra is a GDP közel 40, a költségvetési be vételek 70 és az export 80 százalékát teszi ki (International Monetary Fund, 2019). Az Egyesült Arab Emírségek esetében a szénhidrogénerőforrásoktól való meglehetősen hasonló gazdasági függőséget lát hatunk. Ott az olajiparnak a GDP-hez viszonyított aránya 30 százalék (Theodora.com, 2020).

\section{Gazdasági növekedés és olajfüggóség}

Habár az iráni gazdaság bővülése az elmúlt 50 évben az egész pe riódust tekintve folyamatos volt, az utóbbi évtizedekben jelentős in gadozások jellemezték. Ez akkor lesz szembetűnő, ha csak az el múlt 20 év növekedését vesszüik górcső alá. A stagnálás időszakát (1980-1989), akárcsak az Ahmadinezsád-érát (2005-2013), gazdasági fellendülés követte. 2016-ban, az iráni nukleáris megállapodás (N. Rózsa, 2021) hatályba lépését követően, a McKinsey \& Company globális tanácsadó cég előrejelzése szerint 2035-ig 6 százalékos éves növe kedés volt várható Iránban. Egyes iráni közgazdászok bizonyos fel tételek mellett akár 8 százalékos éves növekedést is elképzelhetőnek tartottak (Dargáhi, 2018, 21. o.). Miután Donald Trump adminisztrációja 2018-ban visszaállította a szankciók egy részét, az iráni gazdaság ismét recesszióba kerüilt, és a Világbank adatai szerint nem valószínú, hogy a következő években jelentősen javulna a helyzete (The World Bank, 2021c). A Nemzetközi Valutaalap (International Monetary Fund, IMF) adatai szerint a koronavírus-járvány a térségbeli államok közül Irán gazdaságát sújtja a leginkább. Bár azt is hozzá kell tenni, hogy az ország gazdasága sokkal jobban teljesített, mint azt korábban várták: a 2020-as előrejelzés ugyanis 6 százalékos zsugorodást prognosztizált (International Monetary Fund, 2020, 23. o.), ehhez képest 1,7 százalékos bóvülés következett be (International Monetary Fund, 2021), ami a riál értékvesztésének és a hazai ipar jobb teljesítményének volt köszönhető (The World Bank, 2021b). 


\section{Külïgyi Szemle}

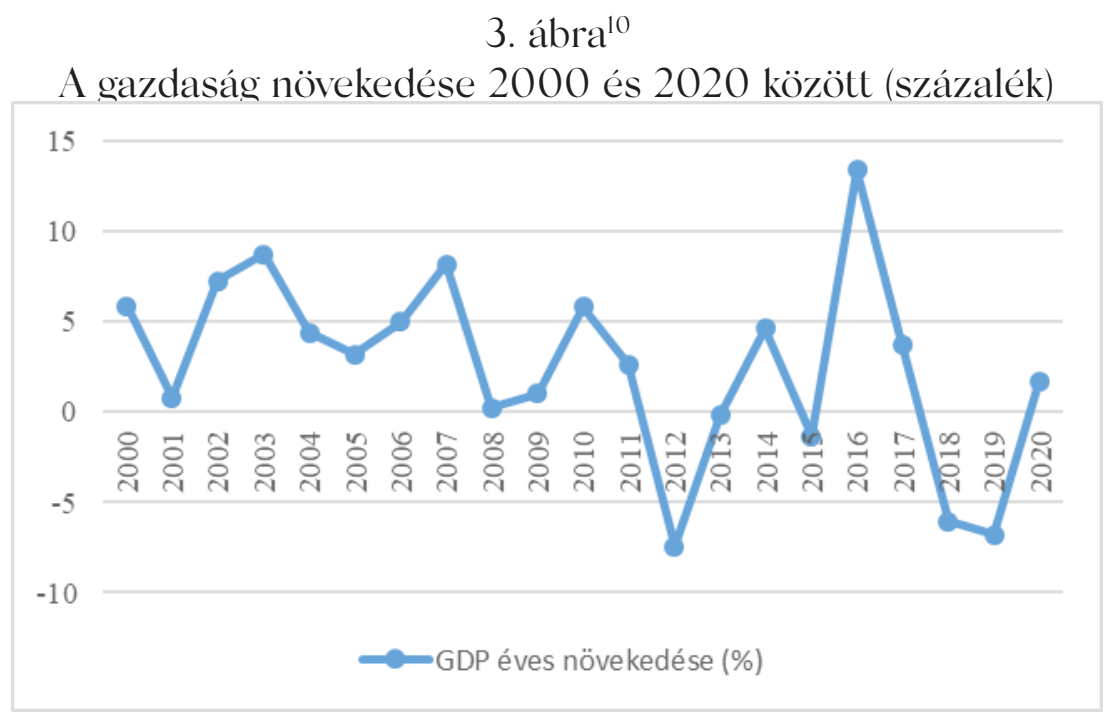

Ha az utóbbi három év negyedéves adatait nézzük, akkor jól láthatóvá válnak a Trump-adminisztráció által kiszabott szankcióknak az iráni gazdaságra gyakorolt hatásai, bár a nem olajra épülő szektorok 2019 első negyedévétől lassú kilábalásnak indultak. A 2020-ban elkezdődött Covid19-válság ezt a növekedést akasztotta meg, bár összességében a statisztikákból az látszik, hogy a járványnak nem volt olyan megrendítő hatása, mint azt az elemzők várták. A 2020. március 20tól 2021. március 20-ig tartó iráni naptári évben az ország statisztikai hivatala szerint a gazdaság 0,7 százalékkal nőtt, míg az olajra épülő kön kívüli szektorok stagnáltak (Statistical Center of Iranian, 2021).

Ennek ellenére azt láthatjuk, hogy bár a jelenlegi szankciók és a koronavírus okozta válság összességében nem roppantották meg az iráni gazdaság szerkezetét, de jelentősen befolyásolják annak növeke dését, így az országnak a 2000-es évek óta a leghosszabb recesszió jával és stagnálásával kell szembenéznie.

10 Forrás: The World Bank, 202la. 


$$
\text { 4. ábra }{ }^{11}
$$

A gazdaság növekedése (százalékban)

az iráni hatóságok által megadott negvedéves bontásban (2018-2021)

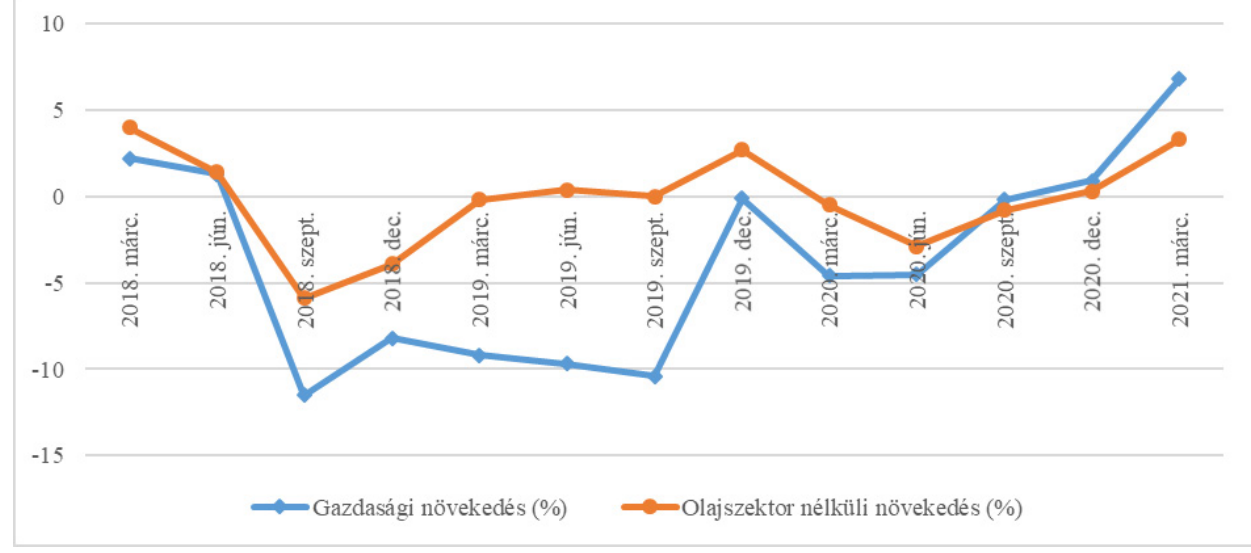

Ezért döntő fontosságú lesz, hogy a közel-keleti ország sikeresen tudja-e tovább mérsékelni az olajtól való függését, amely az állami bevételeknek még mindig az 50 százalékát teszi ki. Bár ez az arány az 1970-es évek óta sokat javult - akkor még több mint 70 százalék volt (Nili, 2010-2011, 271. o.) -, most is nagyon magas, és sebezhetővé teszi az ország gazdaságát (Nili, 2010-2011, 273. o.). Az állami jövedelmek biztosítása érdekében elkerülhetetlen, hogy Irán a jövőben kiszámít hatóbb bevételeket teremtsen. Ebbe az irányba mutat a héa 2008-as bevezetése, valamint a liberalizációs törekvések is, amelyekkel a következő fejezetben foglalkozunk.

\section{Liberalizációs folyamatok az iráni gazdaságban}

Az állam hagyományosan fontos szerepet játszik Irán gazdaságában: más fejlődő országokhoz hasonlóan (Nili és Dargáhi, 2010-2011, 251. o.) a fejlődése és modernizációja motorjaként szolgált (Rostow, 1991, 36. oldaltól). A sah adminisztrációja a szocialista országokban alkalmazott ötéves gazdaságfejlesztési terveket vezetett be, amelyek célja

11 Forrás: Iranian Statistical Office, 2021. 


\section{Külïgyi Szemle}

Irán modernizálása, a kulcsfontosságú gazdasági ágazatokba történő befektetés, illetve banki és biztosítási intézmények létrehozása volt. Ezek a tervek nagyszabású infrastrukturális és iparosítási projekteket irányoztak elő, hogy segítsék az ország tradicionális gazdaságának a fellendülését. Számos olyan iparág, amely jelenleg az iráni gazdaságot alakítja (mint például az autóipar), még a forradalom előtt alakult ki és vált jelentőssé (lásd Rahmánzáde Heravi, 2019).

Ezt a fajta gazdasági tervezési rendszert az iszlám köztársasággá alakulás után is megtartották. Az 1979-es forradalom a nagyszabású államosítási programokkal - részben a kiterjedt etatista befolyás eredményeként - megerôsítette az állam szerepét a gazdaságban (Rahmánzáde Heravi, 2019). E tekintetben a legszélesebb körű intézkedés az új alkotmány bevezetése (1979) volt, amely előírja, hogy a gazdaságnak három - állami, magán-és vállalati szektorból kell állnia (Constituteproject.org, 2021, 44. cikkely). Az alkotmány szerint minden fö iparág az állam irányítása alá tartozik (Constituteproject.org, 2021, 44. cikkely), így megközelítőleg azok 31,2 százalékát államosították a forradalmat követő években (Rahmánzáde Heravi, 2019, 45. o.).

A kilencvenes években azonban ez az államszocialista megközelí tés (Rahmánzáde Heravi, 2019, 40. o.) és az államról alkotott pozitív kép elhalványult. Ennek oka fơként a nagymértékű bürokrácia, az állami vállalatok alacsony hatékonysága (ebből kifolyólag a magas állami költségek), az állam gyenge teljesítménye, az alacsony gazdasági nö vekedés és a gyenge közigazgatás volt (ld. Abrismi, Dorudiján és Nuri, 2016-2017, 183-184. o.). A lehetséges okok között találjuk továbbá a nemzetközi környezet megváltozását, a Szovjetunió összeomlását és a washingtoni konszenzus következtében Iránnak a globális gazdaságban betöltött szerepének az újragondolását. A döntéshozók remélték, hogy - a nyugati országokhoz hasonlóan - egy átfogó privatizáció után hatékonyabb lesz a gazdaság, a költségvetési terhek és a bürokrácia pedig csökkenni fog. Végül, de nem utolsósorban, úgy gondolták, hogy az állam is képes lesz jobban odafigyelni a legfontosabb gazdasági feladataira, például a monetáris és fiskális politikára (Abrismi et al., 2016-2017, 185-193. o.). Ennek hatására a privatizáció kérdése egyre inkább közéleti vitatéma lett. 
E viták 2007-ben érték el a tetőpontjukat, amikor Ali Khamenei, az ország legfőbb vezetóje ígéretet tett az iráni alkotmány 44. \&-ának az újraértelmezésére (Khamenei.ir, 2006). Ezt nem sokkal késóbb követte is az új általános irányelv végrehajtásáról szóló, 2008. január 28-án elfogadott törvény (Surá-je Eszlámi, 2008), amelyet az Örök Tanácsa 2008. június 14-én erősített meg. E szerint a negyedik fejlesztési terv végéig (2009) a kormány felhatalmazást kap arra, hogy eladja az állami cégek részvényeinek 80 százalékát (Surá-je Eszlámi, 2008, 3. cikk). A törvény többek között a bankok, a távközlés, a közle kedés (kivéve: vasút) és a biztosító társaságok privatizációját is tartalmazta (Surá-je Eszlámi, 2008, 2. cikk).

Az átfogó privatizáció során részben a kilencvenes évekbeli kelet európai, főként az oroszországi és lengyelországi „kuponos privatizációs" modellt vették alapul (Abrismi el al., 2016-2017, 113. o.). A korábbi állami cégek kuponokat, úgynevezett ,igazságossági részvényt" (szahm-e adálat) adtak magánszemélyeknek. Ahogy azt a névválasztás (adálat = társadalmi igazságosság) is jelzi, a cél az volt, hogy a lakosság zöme részvényes legyen, s ezáltal csökkenjen a társadalmi egyenlőt lenség (Surá-je Eszlámi, 2008). E politikai irányelv eredményessége azonban vitatható, sőt úgy tủnik, számos ponton egyáltalán nem érte el a kívánt célokat.

Akárcsak Kelet-Európában, a lakosságnak Iránban sem voltak meg sem a képességei, sem az anyagi forrásai ahhoz, hogy részvényes le gyen. (Az oroszországi példát ld. Burawoy, 1994.) Így azoknak a vállalatoknak, amelyek magántulajdonba kerültek, komoly nehézségekkel kellett megküzdeniük, hogy friss tókéhez jussanak (lásd Abrismi et al., 2016-2017, 119. o.). Kelet-Európában a külföldról érkező tömeges tô kebeáramlás meg tudta oldani ezt a problémát, azonban Iránban a 2012-tôl, azaz még az Ahmadinezsád-érában kezdődött, egyre növekvő szankciók következtében a vállalatoknak csak korlátozott lehetőségeik voltak, hogy a küllö̈ldi és belföldi piacokról fedezzék a tőke igényüket. A tőzsdére lépés után jó néhány cég akár 80 százalékos értéknövekedést is tapasztalt a mérlegében - de nem a tỏkebeáramlás, hanem a megváltozott értékelési módszerek miatt (Rahmánzáde Heravi, 2019, 65. o.). 


\section{Külïgyi Szemle}

Ráadásul, mivel a forradalom után több korábbi menedzser el hagyta az országot, a szakértelem is hiányzott a cégek irányításához (Rahmánzáde Heravi, 2019, 64. o.). Tulajdonképpen sok esetben az új magántulajdonosok rosszabb szolgáltatást nyújtottak az ügyfeleknek, mint az államiak (ahogy azt Hoszejn Dorudiján és társai szemléltetik a teheráni tömegközlekedési rendszer részleges privatizációja kap csán (Atrkar Roshan, Shirinbakhsh, Esfandyar és Doroudian, 2015).

Ezek a kérdések döntő szerepet játszottak abban, hogy az iráni privatizációs folyamat a hiányzó politikai és társadalmi támogatás miatt az átalakuló közép- és kelet-európai országokéhoz képest „félúton” megrekedjen. Habár az alkotmány 44. cikkére vonatkozó, az általános irányelv végrehajtásáról szóló törvény számos olyan feltételt tartalmaz, amely tisztességes versenyt biztosít, és korlátozza a monopóliumokat (Constituteproject.org, 2021, 43-84. cikkely) - mint az 1890. évi amerikai Sherman trösztellenes törvény átültetése (ld. Dunjá va Iqtiṣzād, 2017) -, azok a gyakorlatban kevésbé jutottak érvényre.

A privatizációs hullám következtében az államnak a gazdaság ban betöltött szerepe mindezek ellenére jelentősen csökkent. Míg az 1383-as naptári évben (2004-2005) az aránya 33,7 százalék volt, a negyedik ötéves terv végére 19,5 százalékra csökkent (Kordbaccse, 2010-2011. 168. o.). Ez a változás az ország egyik legnagyobb gazdaságtörténeti eseménye az iszlám forradalom óta (lásd Rahmánzáde Heravi, 2019, 64. o.).

\section{Egyes gazdasági ágazatok elemzése}

Tanulmányunk következô részében az iráni gazdaság egyes ágazatait elemezzük, és megpróbáljuk nyomon követni, hogy a felsorolt események hogyan hatottak a gazdaság egészére, valamint igyekszünk arról teljes képet adni. Az Iráni Statisztikai Központ négy kategóriába gyűjti az egyes gazdasági ágazatokat. Ezek: mezőgazdaság, olaj, ipar és bányászat, illetve szolgáltatások. E cikkben - az egyszerúség kedvéért - ezt a kategorizálást követjüik, de fontos megjegyezni, hogy némely adat pontatlan lehet, és az egzakt besorolás is megkérdőjelezhető (Rahmánzáde Heravi, 2019, 317. o.). 
A következő táblázat a teljes bruttó értéket mutatja (milliárd irá ni riálban, rögzített áron), továbbá a négy szektornak az iráni bruttó nemzeti jövedelemhez viszonyított százalékos arányát az iráni 1392 1396. naptári évek között (2013. március 21.-2018. március 20.).

\section{1. táblázat ${ }^{12}$}

A GNI alakulása és megoszlása a négy szektor között, 1392-1396 [2013-2018]

(az 1390. évi árszínvonalon rögzítve, milliárd riálban)

\begin{tabular}{|c|c|c|c|c|c|c|c|c|c|c|}
\hline Év & \multicolumn{2}{|c|}{$1392(2013-14)$} & \multicolumn{2}{|c|}{$1393(2014-15)$} & \multicolumn{2}{|c|}{$1394(2015-16)$} & \multicolumn{2}{|c|}{$1395(2016-17)$} & \multicolumn{2}{|c|}{$1396(2017-18)$} \\
\hline Szektor & Összeg & $\%$ & Összeg & $\%$ & Összeg & $\%$ & Összeg & $\%$ & Összeg & $\%$ \\
\hline $\begin{array}{l}\text { Mező- } \\
\text { gazdaság }\end{array}$ & 405 & 6,7 & 424 & 7,1 & 442 & 6,6 & 456 & 6,7 & 452 & 6,9 \\
\hline Olaj & 880 & 14,6 & 943 & 15,9 & 1524 & 22,8 & 1539 & 22,2 & 1260 & 19,1 \\
\hline Ipar & 1646 & 27,2 & 1546 & 26,0 & 1580 & 23,6 & 1660 & 23,9 & 1588 & 24,1 \\
\hline $\begin{array}{l}\text { Szolgál- } \\
\text { tatások }\end{array}$ & 3277 & 54,2 & 3202 & 53,8 & 3316 & 49,6 & 3462 & 49,9 & 3442 & 52,4 \\
\hline Összesen & 6043 & 100 & 5947 & 100 & 6691 & 100 & 6941 & 100 & 6565 & 100 \\
\hline
\end{tabular}

A legfrissebb adatok azt mutatják, hogy a szankciók visszaállítá sáig a mezőgazdaság, az ipar és a szolgáltatási szektor növekedése többé-kevésbé állandó volt, de az olajágazat mérete majdnem a duplájára nőtt, és az aránya meghaladta az iráni bruttó nemzeti jövedelem 20 százalékát. Ez annak köszönhető, hogy a 2016-ban felol dott szankciókkal Irán jelentősen növelhette az olajexportját, és az olajárak is kedvezően hatottak az ország gazdaságára.

A szankciók ismételt bevezetése után egy érdekes tendencia volt megfigyelhető: míg az olajágazatnál jelentős, majdnem 20 százalékos zuhanás történt, addig a többi ágazatnál korántsem mutatható ki ilyen mértékű visszaesés, tehát az iráni gazdaság egésze sokkal krízisállóbbnak bizonyult, mint azt sokan gondolták. Hozzá kell tenni, hogy

12 Forrás: Central Bank of the Islamic Republic of Iran, 2020a; Iran Chamber of Commerce, Industries, Mines \& Agriculture, 2018, 51. o., 2. és 3. táblázat; Presidency of the I.R.I. Plan and Budget Organization, 2021, 49. o. 2. táblázat. 


\section{Külïgyi Szemle}

természetesen végső értékelést ez ügyben csak a 2020-2021. évi sta tisztikák rendelkezésre állását követően adhatunk.

A következőkben kicsit behatóbban fogjuk megvizsgálni az iráni gazdaság egyes szektorait és a liberalizációs politika hatásait.

\section{A szolgáltatási szektor}

Az Iráni Központi Bank meghatározása szerint a szolgáltatások „olyan nem tárgyiasult javak, mint például az egészségügy, az oktatás, a szállítás és a lakhatás" (Central Bank of the Islamic Republic of Iran, 73. o.). Amint azt korábban bemutattuk, a három klasszikus gazdasági ágazat közül Iránban a szolgáltatási szektor a legerősebb. Az adja a GDP több mint 50 százalékát. Az iráni statisztikai hivatal ezt a nagy területet hét alkategóriára osztja:

- kereskedelem, vendéglátás és szállodaipar;

- szállítás, raktározás és kommunikáció;

- pénzügyi szolgáltatások (banki, biztosítási stb.);

- ingatlan- és egyéb speciális szolgáltatások;

- közszolgáltatások (egészségüigy, munkanélküli biztosítás stb.);

- szociális szolgáltatások.

Az 5. ábra a szolgáltatási szektornak az iráni naptár szerinti 1338 1393 közötti években (1959. március 22. és 2015. március 20.) történt fejlődését mutatja, a küiönböző alkategóriák szerint. A szaggatott vo nal az iszlám forradalmat jelöli.

Az első tendencia, amit az ábráról leolvashatunk, hogy a szolgáltatási szektor az iráni-iraki háború vége óta folyamatosan növekedett. Ez igaz a nettó kibocsátására éppúgy - amely az iszlám forradalom óta több mint a duplájára nôtt -, mint az iráni gazdaságban elfoglalt helyzetére. Míg 1978-ban a szolgáltatásokból eredt az ország GDPjének körüilbelül 50 százaléka, 2015-ben ez az arány 60 százalékra emelkedett. Ha azonban összehasonlítjuk az ország GDP-jének a nem olajból származó arányát, akkor csökkenést tapasztalhatunk: 1978-ra 83-ról 67 százalékra csökkent. A második tendencia a szolgáltatási 
szektoron belüli jelentős átszervezésekre utal. Míg a hetvenes évek közepén a köz- és a pénzüigyi együtt az összes szolgáltatás körüilbelül 60 százalékát adta, 2015-ben a 20 százalékot sem érték el. Másrészrôl a szállítás és a kommunikáció viszont óriási növekedést mutatott, különösen a 2000-es évek közepe óta, a piac liberalizálását követően. Az ingatlanokkal kapcsolatos és egyéb szolgáltatások is jelentősen bővültek.

\section{5. ábra ${ }^{13}$}

A szolgáltatási szektor fejlődése Iránban, 1959-2015 (milliárd riál, rögzített áron)

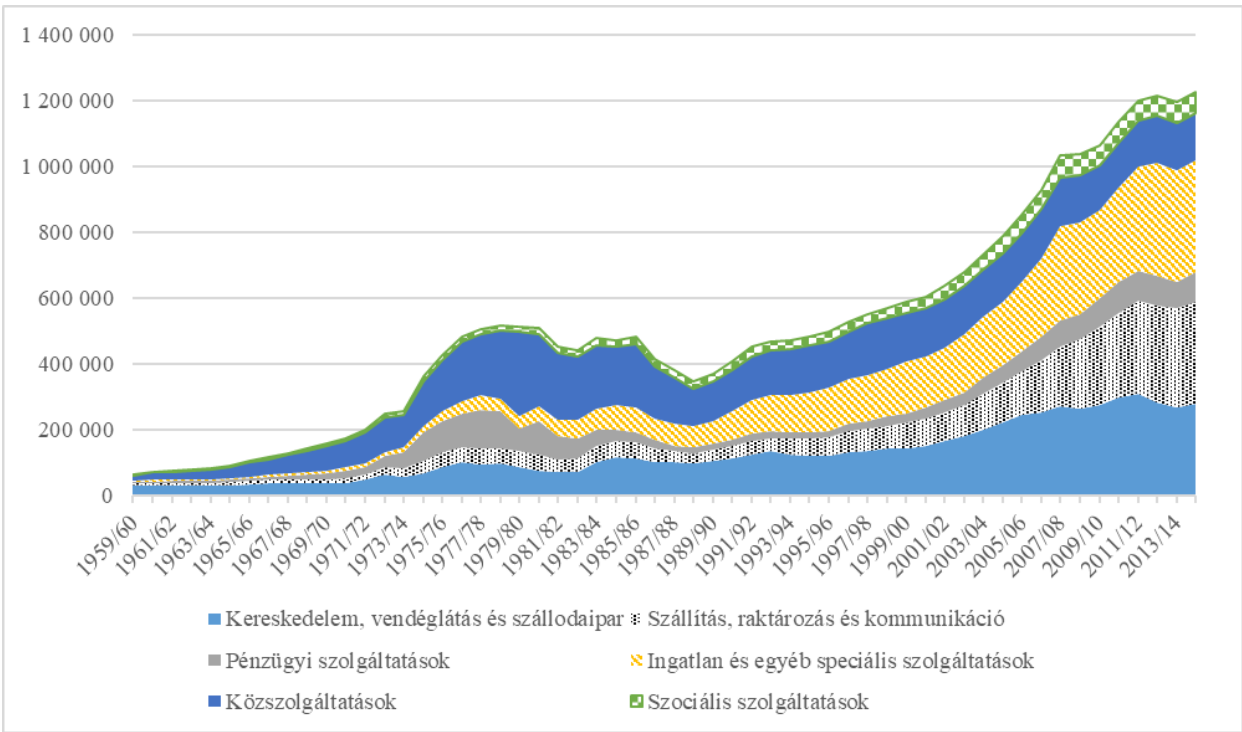

Kereskedelem, éltermek és szállodaipar

Az 1394-es iráni statisztikai évben (2015-2016) a kereskedelemből, az éttermekből és a szállodaiparból származó forgalom 859.819 milliárd riált tett ki, ebből az utóbbi kettő együttesen is csak elenyésző

13 Forrás: Central Bank of the Islamic Republic of Iran, 2020c. 


\section{Külïgyi Szemle}

mértékben, 23.126 milliárd riál értékben (2,7 százalék) vette ki a ré szét. ${ }^{14}$ A bejegyzett kereskedelmi egységek túlnyomó többségét egy személyes vállalkozások (pl. bazári üzletek) képviselték. Az arányuk 72 százalék volt. Az ötnél több fơt foglalkoztató szolgáltatóvállalatok aránya nem érte el az 1 százalékot sem - legalábbis a 2003-as statisztika szerint, azóta ugyanis e területtel kapcsolatosan nem állnak rendelkezésre adatok (Rahmánzáde Heravi, 2019, 442. o.). A „nyugati stílusú” bevásárlóközpontok és szupermarketek megjelenése következtében ez a szám talán már növekedett (Rahmánzáde Heravi, 2019, 442., 445. o.), de ezt újabb adatok még nem bizonyítják.

Továbbá megfigyelhető a turizmusszektor folyamatos növekedése is: a 2018-2019-es naptári évben az iráni szállodák 245.718 ágyat biztosítottak vendégeiknek a különböző kényelmi kategóriákban. Ez 2000-hez képest több mint négyszeres növekedés, bár az ágykapacitás egy Iránhoz hasonló, rendkívül jelentős kulturális örökséggel és idegenforgalmi potenciállal rendelkező országhoz viszonyítva még mindig nagyon alacsony. Összehasonlításképpen: a kisméretű európai átalakuló gazdaságú országnak számító Magyarországban 838.398, a nála jóval nagyobb Németországban 6.947.260, míg az idegenforga lom szempontjából kiemelkedő Olaszországban 10.626.340 férőhe lyet tudnak biztosítani (European Commission, 2020).

Az alábbi táblázat a kiválasztott szálláshelyek minôség szerinti eloszlását mutatja.

2. táblázat $^{15}$

A GNI alakulása és megoszlása a négy szektor között

\begin{tabular}{|c|c|c|c|c|c|}
\hline Kategória & Hostel & $\begin{array}{c}\text { Egyéb } \\
\text { (apartman, } \\
\text { panzió stb. })\end{array}$ & $\begin{array}{c}\text { Alacsony } \\
\text { kategóriás } \\
(1-2 \text { csillagos } \\
\text { hotel })\end{array}$ & $\begin{array}{c}\text { Közép- } \\
\text { kategóriás } \\
(2-3 \text { csillagos } \\
\text { hotel })\end{array}$ & $\begin{array}{c}\text { Prémium } \\
\text { kategóriás } \\
(4-5 \text { csillagos } \\
\text { hotel })\end{array}$ \\
\hline 1380 & Nincs adat & Nincs adat & $19,4 \%$ & $13,5 \%$ & $13,8 \%$ \\
\hline 1396 & $25 \%$ & $27 \%$ & $17,0 \%$ & $15,0 \%$ & $16,0 \%$ \\
\hline \hline
\end{tabular}

14 Az 5. ábrával ellentétben ezek folyóáras adatok, tehát nem veszik figyelembe az inflációt - innen adódnak különbségek.

15 Presidency of the I.R.I. Plan and Budget Organization, 2021, 446. o. 
A legtöbb ágy alacsony kategóriás hostelekben, az úgynevezett mihmanpazirban található, a leggyakrabban 2-3 ágyas szobákban. Az utóbbi 16 évben azonban a prémium kategóriás létesítmények száma is enyhe növekedést mutat.

\section{Szállitás és kommunikáció}

Az 1396-os iráni naptári év végére (2018. március) a szállítás és a kommunikáció alszektor a teljes szolgáltatásnak 18,24, Irán GDP-jének pedig körülbelül 10 százalékát tette ki (Central Bank of the Islamic Republic of Iran, 2020a, 48. o.). 2016-ban a közúti, vasúti, hajóval vagy repüilőgéppel történő szállítás az alágazat forgalmához 83,4 százalékban járult hozzá (Central Bank of the Islamic Republic of Iran, 2020b), míg a kommunikációs cégek 13,5 százalékban - közülüik is főként a mobilszolgáltatók.

Az alábbi táblázat az egyes közlekedési eszközök teljesítményét és azok eloszlását mutatja.

3. táblázat ${ }^{16}$

A közlekedési eszközök teljesítménye

\begin{tabular}{|l|c|c|c|c|}
\hline Forgalom & $\begin{array}{c}\text { Utasok } \\
\text { Smillítóeśember) }\end{array}$ & $\begin{array}{c}\text { Azzösszeshez } \\
\text { viszonyított } \\
\text { aránya }\end{array}$ & $\begin{array}{c}\text { Áru } \\
\text { (millió tonna) }\end{array}$ & $\begin{array}{c}\text { Az összeshez } \\
\text { viszonyított } \\
\text { aránya }\end{array}$ \\
\hline Közúti & 154,00 & $65,90 \%$ & 480,00 & $70,20 \%$ \\
\hline Vasúti & 24,50 & $10,50 \%$ & 46,80 & $6,80 \%$ \\
\hline Tengeri & 19,40 & $8,30 \%$ & 156,80 & $22,90 \%$ \\
\hline Légi & 35,80 & $15,30 \%$ & & - \\
\hline
\end{tabular}

Iránban a szállítás nagyobb része ma közúton történik. Ez nem csoda, ha az ország infrastruktúrájának a fejlődését nézzüik. Az utóbbi években a legtöbb infrastrukturális beruházás az úthálózatot célozta. Az ezredforduló óta a jó minőségű utak (autópályák és országutak) teljes hossza megnégyszereződött: 5.000 -ről 20.000 km-re emelkedett (Presidency of the I.R.I. Plan and Budget Organization, 2021, 455. o.). 16 Presidency of the I.R.I. Plan and Budget Organization, 2021, 7. o. 


\section{Külïgyi Szemle}

Másrészt a többi közlekedési eszköz óriási fejlesztési potenciállal rendelkezik. Irán vasúti hálózata csupán 11.061 km hosszú (Presidency of the I.R.I. Plan and Budget Organization, 2021, 455. o.) - ami nagyjából a kis területû Cseh Köztársaság pályahosszának felel meg. Az állami vasúttársaság elavult infrastruktúrával és gépekkel rendelkezik. Az elmúlt években tervezett nagyberuházások többnyire nem valósultak meg (Rahmánzáde Heravi, 2019, 453-454. o.). Irán felújításra szo ruló vasúthálózata más szempontból is szűk keresztmetszetet jelent, mivel jelentősen akadályozza a déli országrész kikötőinek a tervezett fejlesztését (Rahmánzáde Heravi, 2019, 456. o.).

Ugyanez igaz Irán légi közlekedésére is. Annak ellenére, hogy az ország légitársaságai az iszlám forradalom előtt a legjobbnak számítottak, manapság a repüilőgépek elavultak, és többnyire már használtan szerzik be őket (Rahmánzáde Heravi, 2019, 495. o.). Pozitív tendenciának tekinthető, hogy az utóbbi 20 évben a vidéki repüilőterek egymást követő fejlesztése zajlott, így - látszólag - javult a belföldi járatok minősége. 2018 márciusáig az összes légi utas kétharmada hazai útra vett jegyet (Central Bank of the Islamic Republic of Iran, 2020d).

Az iráni távközlési ipar komoly változáson ment keresztül az első távíró vonal 1877-es kiépítése óta (Rahmánzáde Heravi, 2019, 474. o.). Hosszú ideig az ország egyik kulcsfontosságú iparága volt, s az alkotmány 44. §-a szerint állami igazgatás alá tartozott. Azok az idők azonban elmúltak az iparág 2009-es privatizálásával. Habár magát a privatizációs folyamatot sokszor kritizálták az átláthatóság hiánya miatt (Rahmánzáde Heravi, 2019, 474. o.), manapság a három fő magánszolgáltató - a Hamrah Avval, az Irancell és a Raytel - szinte teljes hálózati lefedettséget biztosít az országban, és az irániak 70 százaléka rendelkezik internet-hozzáféréssel (United Nations Development Programme, 2020). 
A 1396-os (2017-2018) pénzügyi év teljes bevétele 482.000 milliárd riálra tehető folyó áron, így a pénzüigyi szolgáltatások az iráni GNI 3,9 százalékát tették ki (Central Bank of the Islamic Republic of Iran, 2020a, 48. o.). Ebből az összegből a banki üzletág részaránya 83, míg a biztosításé 15 százalék volt. Ha csak a számokat vesszüik figyelembe, a pénzügyi szektornak a teljes gazdasági teljesítményhez viszonyított aránya körüilbelüil a fejlett Németországénak felel meg (Statista, 2021), míg más mutatók esetében, mint pl. az egy fơre jutó ATM-ek számában, még meg is haladja azt (Dobbs, Hatami, Allas, Arab és Mahtafar, 2016, 9. o.). A többi esetében azonban világossá válik, hogy Irán pénzügyi szektora számos nehézséggel küzd (Iqtisad Online, 2016). Ahogy arra az IMF 2018-as, Irán pénzügyi szektorával kapcsolatos jelentése rámutatott, a bankszektort a nemteljesítő hitelek, a zárolt tőke magas aránya és a nem megfelelő felügyelet jellemzi (IMF eLIBRARY, 2018, 14. o.). A lakosság pénzügyi múveltsége minimális, a biztosítási penet ráció még mindig nagyon alacsony a fejlett országokéhoz képest (De Souza Rodrigues Cabral, Dornigg, Kubli és Staib, 2020).

Az iráni bankipar története a 19. század végére nyúlik vissza, amikor a britek megalapították az első kereskedelmi bankot Teheránban. A bankjog alkalmazása 1955-ben kezdődött (Majlis.ir, 1955), majd 1972. július 9-én elfogadták „az ország monetáris és banki törvényét”, amely a mai napig meghatározza az iráni bankszektor jogviszonyát (Majlis.ir, 1972). A forradalom előtt összesen 35 bank múködött az országban, 8300 fiókkal. Az intézmények nagy része magánkézben volt, több küllföldiben vagy közös vállalkozásban (Rahmánzáde Heravi, 2019, 490-491. о.).

A bankszektor átszervezése a forradalom után három nagy lépés ben történt. Az első törvényt 1979. június 7-én rendelte el a forradalmi tanács, amellyel gyakorlatilag államosították az egész bankszektort (Majlis.ir, 1979c). Az iparvédelmi és fejlesztési törvényt egy hónappal később, 1979. július 1-jén hozták meg, amely megerósítette a korábbi döntést (Majlis.ir, 1979b). A harmadik, a banki ügyek kezeléséről 


\section{Külïgyi Szemle}

szóló törvényt 1979. szeptember 4-én fogadták el, s az meghatározta a központosított bankrendszer szerkezetét (2. \$), és előkészítette az utat a bankszektor iszlamizálásához (22. \$) (Majlis.ir, 1979a), ami hivatalosan 1983. augusztus 30-án történt meg, a kamatmentes banki múveletekre vonatkozó törvény elrendelésével (Majlis.ir, 1983). E két törvény nagyjából kialakította a bankszektor múködését a következő húsz évre.

A bankrendszer liberalizálása a harmadik gazdaságfejlesztési tervvel (2000-2004) vette kezdetét, amely a forradalom óta először tette lehetővé a magánbankok létrehozását. A banktörvény módosítására azért volt szüikség, hogy „fokozzák a versenyfeltételeket a pénzügyi piacokon, ösztönözzék a megtakarításokat és a befektetéseket, megteremtsék a talajt az ország gazdasági növekedéséhez és fejlődéséhez, és minimalizálják a társadalmi költségeket" (Majlis.ir, 2000, 98. \$). A felügyeleti szerv 2000-ben engedélyezte a magán bankok létrehozását.

A 2008-ban kezdődött privatizációs hullám a bankszektort is elérte: három bankot magánosítottak, tizenhetet újonnan alapítottak, és nyole állami kézben maradt. A privatizációs folyamat ellenére sem beszélhetünk azonban piacorientált bankszektorról. A legnagyobb jegyzett tőkével rendelkezô bankok állami kézben maradtak, és 2016 márciusában az állam piaci részesedése 46,38 százalék volt (Rahmánzáde Heravi, 2019, 499. o.). Ha pedig figyelembe vesszüik a küilönböző félállami formációknak a küilönböző bankokban való része sedését, akkor biztosan kijelenthetjük, hogy a bankszektort gyakorlatilag az állam irányítja (a Sina Bank esetében például a Mostazafan Alapítvány az összes részvény 81,9 százalékát birtokolja) (Sahamyab. com, 2020).

Ami a biztosítási ágazatot illeti, hasonló képet kapunk: Iránban jelenleg 32 aktív biztosítótársaság múködik, de nyole uralja a piac kb. 80 százalékát. Az állami kézben lévő Bimeh Iran vállalat rendelkezik a legnagyobb piaci részesedéssel, 42,5 százalékkal (Central Bank of the Islamic Republic of Iran, 2020d, 243. o.). 
Az ágazat legfontosabb gazdasági feladata, hogy számszerúsíthetővé tegye a kockázatokat, és segítse a gazdasági szereplőket abban. hogy jobban előre tudják látni a jövendőbeli bevételeiket, és felszabadíthassák az erőforrásaikat egyéb célokra. Jelenleg Irán biztosítá si szektora csak korlátozott mértékben tudja ellátni ezt. A vonatkozó jogszabályok régiek és elavultak. E téren a biztosítási törvény (1937) és a biztosítási felügyeleti törvény (1971) - mindkettő a francia jogból átvett jogszabály - elfogadása óta nem történt komoly változás.

A kiterjedt állami szerepvállalás miatt nincs valódi termékválasz ték, és alapvetően nincs hatékony verseny a cégek között - ez pedig sem a marketingre, sem az ügyfél-kommunikációra nem hat ösztönzóleg (Hásemi, 2018-2019 [1397], 17-18. o.). Az iráni biztosítási piacot nagyrészt az autókkal kapcsolatos szegmens uralja (gépjármú-, felelősség- és balesetbiztosítás), amely 2018-ban az összes biztositási dij 47,7 százalékát tette ki (Presidency of the I.R.I. Plan and Budget Organization, 2021, 543. o.). ${ }^{17}$ Az önrész és a dịjak megfelelő kom binációjával a biztosítás az ügyfelek kevésbé veszélyes magatartását erősítené. Iránban ugyanis rendkívül magas a közúti balesetek száma (4.920.100 évente) - és növekvő tendenciát mutat (Iran Chamber of Commerce, Industries, Mines \& Agriculture, 2018, 103. o.) -, míg a hasonló lélekszámú Németországban 2,64 millió (Gefahrenstellen.de, 2021), amelyek közül halálos kimenetelúvé válik Iránban 17.000, Né metországban pedig 3.100. Ez részben szomorú összegzés Irán nem megfelelően múködő biztosítási rendszeréről is.

Végül, de nem utolsósorban a szankciók megakadályozzák az iráni biztosítókat abban, hogy küllöldről kapjanak viszontbiztosítási fedezetet, ezért szinte minden kockázat az országon belül marad. Mivel az országot évente több súlyos természeti katasztrófa is éri (pl. földrengések és árvizek), ez megterhelő az állami szektor számára, a biztosítótársaságok pedig vonakodnak attól, hogy növeljék a kötvények számát, mivel egy súlyos katasztrófa csődbe viheti őket. Hatalmas kihívás mindemellett a technológiatranszfer is, ugyanis az

17 A fejlett ipari országokban az életbiztosítások uralják a piacot: a részarányuk meghaladja az 50 százalékot is (De Souza Rodrigues Cabral, Dornigg, Kubli és Staib, 2020). 


\section{Külïgyi Szemle}

iráni biztosítók csak nehezen juthatnak hozzá a kárkalkuláció elkészítéséhez szükséges korszerú szoftverekhez, ami szintén hátráltatja a szektor hatékony múködését (Central Insurance of the Islamic Republic of Iran, 2019). Az iráni szállítók nem köthetnek biztosításokat sem a nemzetközi piacokon, így ez további többletterhet jelent a hazai biztosítási szektorra.

Összefoglalásként kijelenthető, hogy az iráni szolgáltatási szektor az utóbbi fél évszázadban nagy átalakuláson ment keresztül. Túlzás nélkuil állíthatjuk, hogy az ágazat növekedése azt jelzi, hogy Irán népe a hagyományos modell követése helyett modern társadalommá alakul át. A mobilalkalmazás segítségével történő ételrendelés és az online fizetés manapság több millió iráni életének a szerves része. A legtöbb család számára a legközelebbi ATM alig 10 percnyi sétára található - de miért is foglalkoznának a pénzfelvétellel, ha a helyi bazár és zöldséges is elfogad hitelkártyát?

Ugyanakkor az ágazatnak komoly kihívásokkal és elégtelenséggel kell szembenéznie. A korábban állami tulajdonban állt vállalatok 2000-es évekbeli privatizációja, a távközlést kivéve, még nem könyvelhető el sikertörténetként. Hiányos és elavult jogszabályok, hiányzó üzleti kultúra és vezetői képességek jellemezték a szolgáltatásokat az elmúlt 10 évben. A pénzügyi szektornak, amelynek a magánvállalkozások számára anyagi forrásokat és biztonságot kellene nyújtania, a feladata ellátásához csak korlátozott lehetôségei vannak. Mind a ban ki, mind a biztosítási ágazatot de facto az állam ellenőrzi, és a termékportfóliójuk nem felel meg a valós piaci igényeknek. Ez komolyan akadályozza az ország modernizációs törekvéseit, mivel sem az államnak, sem a magánvállalkozásoknak nem igazán kínálkozik módjuk arra, hogy hitelekhez és biztosításhoz jussanak.

\section{Ipar}

A bruttó hazai termékhez való általános hozzájárulása alapján az ipar és a bányászat a szolgáltatási szektor után az iráni gazdaság második legnagyobb szegmense. 
A helyi statisztikákban az ágazat négy alcsoportra oszlik. Ezek: a feldolgozóipar, a bányászat, a villamos energia, vízgazdálkodás és gáztermelés, valamint az építőipar. A 4. táblázat áttekintést nyújt az e kategóriákon belüli, 2013. március 21. és 2018. március 20. közötti megoszlásról és trendekről.

\section{4. táblázat ${ }^{18}$}

A közlekedési eszközök teljesítménye

(forgalom, 1000 milliárd riálban)

\begin{tabular}{|l|r|r|r|r|r|r|r|r|r|r|}
\hline \multicolumn{1}{|c|}{ Iráni év } & \multicolumn{2}{|c|}{1393} & \multicolumn{2}{|c|}{1394} & \multicolumn{2}{c|}{1395} & \multicolumn{2}{|c|}{1396} & \multicolumn{2}{c|}{1397} \\
\hline Alszektor & Forg. & $\%$ & Forg. & $\%$ & Forg. & $\%$ & Forg. & $\%$ & Forg. & $\%$ \\
\hline Bányászat & 56 & 3,4 & 50 & 3,2 & 51 & 3,2 & 53 & 3,2 & 53 & 3,3 \\
\hline $\begin{array}{l}\text { Feldolgozó- } \\
\text { ipar }\end{array}$ & 766 & 46,5 & 731 & 47,2 & 781 & 49,4 & 823 & 49,6 & 757 & 47,7 \\
\hline $\begin{array}{l}\text { Villamos- } \\
\text { energia }\end{array}$ & 402 & 24,4 & 416 & 26,9 & 444 & 28,1 & 477 & 28,7 & 488 & 30,7 \\
\hline Építőipar & 421 & 25,6 & 349 & 22,6 & 303 & 19,1 & 307 & 18,5 & 290 & 18,3 \\
\hline Összesen & 1646 & 100 & 1546 & 100 & 1580 & 100 & 1660 & 100 & 1588 & 100 \\
\hline
\end{tabular}

A legutóbbi statisztikai adatok szerint az utolsó válság elótti évben az ágazat egésze 1,66 százalékos éves növekedést produkált. Azon belül a legnagyobbat, 6,43 százalékot, a villamos energiát, a vízgazdálkodást és a gáztermelést tartalmazó szegmens érte el. A szankciók kicsúcsosodásának hatására az ágazat a 2019-2020-as naptári évben több mint 4 százalékos visszaesést szenvedett el - ez az olajágazaté utáni legnagyobb mértékủ recessziónak számított. Az is megfigyelhe tő, hogy a szankciók nem egyformán érintették a különböző ágazatokat. Míg a bányászat és a villamos energia stagnált vagy enyhe növe kedést ért el, addig az építőiparnak gyenge (5,5\%), a feldolgozóiparnak pedig jelentósebb (8\%) visszaeséssel kellett szembesülnie.

A következőkben mélyrehatóbban foglalkozunk a feldolgozóiparral, mivel a közel 50 százalékos arányával ez a csoport legjelentősebb alágazata.

18 Forrás: Iran Chamber of Commerce, Industries, Mines \& Agriculture, 2018, 51. o. 2. táblázat. 


\section{Külïgyi Szemle}

Irán legjelentősebb iparága az autógyártás. Jelenleg ez biztosít ja a legtöbb munkahelyet az országban. $A z$ autóipar az iszlám for radalom előtti időkben alakult ki. Valójában mindkét fó vállalat, a Khodro Pars és az Iran National (az Iran Khodro elódje) a hatvanas években alakult meg, még magáncégként. Eleinte dzsipekre és katonai járművekre összpontosítottak (Rahmánzáde Heravi, 2019, 272. o.), és a hetvenes évekbeli virágzásuk idején (az iszlám forradalom elótti utolsó 10 évben) az éves forgalmuk meghaladta az 1.1 millió jármúvet (Rahmánzáde Heravi, 2019, 272. o.).

A forradalom után az egész iparágat államosították, és a nem megfelelő hatékonyság és a nagy bürokrácia miatt - az irányított gazdaság más ágazataihoz hasonlóan - komoly kihívásokkal kellett szembenéznie. Sok kisebb cég bezárt, illetve kínai vagy koreai vállalatoknak adták el őket (Rahmánzáde Heravi, 2019, 269. o.).

Teljesítmény tekintetében napjainkban Irán a világon a 18., a Közel-Keleten pedig Törökország után a második legtöbb autót gyártó ország. Jelenleg azonban az iparág csak a belföldi keresletet fedezi, nemzetközileg nem versenyképes. Az országgal szemben fennálló nemzetközi szankciók következtében az ellátásbeli problémák, a befektetési lehetőségek hiánya, a politikai instabilitás, a következetlen vámpolitika és a rossz irányítás egyaránt komoly problémákat okoz az autóiparban (Tehran Times, 2019).

Ami a többi iparágat illeti, az Iráni Statisztikai Központ jelenté se szerint az 1396-os iráni naptári évben (2017-2018) 31.309 gyár működött az országban, amelyben összesen 1.788 .651 munkavállalót foglalkoztattak. Ez a teljes munkaerő 5,7 százalékát tette ki. A gyárak túlnyomó többsége (körüilbelül 80 százaléka) maximum 50 föt alkalmazó kisvállalkozás volt, s mindössze 9,6 százalékuk foglalkoztatott 100 vagy annál több munkást, azonban így is ôk biztosították a megélhetést az összes munkavállaló 58,7 százalékát. Megfigyelhető ugyanakkor a nóknek a foglalkoztatásban képviselt alacsony aránya is, ami - a legtöbb MENA-országhoz ${ }^{19}$ hasonlóan - többé-kevésbé az

19 Middle East and North African countries, azaz a Közel-Kelet és Észak-Afrika országai. 
egész iráni gazdaságot jellemzi (Cseh, Varga és Bánkuti, 2019). Míg az iráni statisztikák szerint az ezredfordulón az ágazat összes dolgozójának mindössze 5,33 százaléka volt nő, 2017-ben ez az arány 9,07 százalékra nótt (Presidency of the I.R.I. Plan and Budget Organization, 2021, 321. o.), ami azonban még mindig meglepően alacsony a fejlett országokéhoz képest.

Az iszlám forradalom és az ezredforduló között az iráni iparágakat nagy állami szerepvállalás jellemezte, amelynek alapja két kulcsfontosságú 1979-es törvény volt.

Az elsőt, az iparvédelmi és fejlesztési törvényt a forradalmi tanács nem sokkal a hatalomátvétel után, 1979. július 1-jén fogadta el. A szövegezése szerint a régi rezsim a felelős azért, hogy az iparpolitikájával elpusztította az ország mezőgazdaságát, és a küllöldi tőkétől tette függôvé az országot. A megfogalmazott cél ezért többek között az iráni gazdaságnak az olajfüggőségtől való megszabadítása, az önellátás elérése és az összes kulcsfontosságú ipari ágazat és nagyobb gyár államosítása (Majlis.ir, 1979b). A második az iráni alaptörvény volt, amelynek a 44. cikkelye kikötötte, hogy minden kulcsfontosságú iparágnak az államhoz kell tartoznia.

A politikai irányváltás mellett a 2005-2012 közötti privatizációs hullám is jelentősen érintette a szektort, mivel a nagyobb termelési egységeket és gyárakat magánosították. A statisztikai adatok szerint jelenleg a gyárak túlnyomó része magánkézben van. Az előzô 16 évhez képest egyértelmú elmozdulás volt megfigyelhetô a magánszektor felé, és az állam tulajdonában lévő gyárak száma folyamatosan csökkent. Ha összehasonlítjuk az iráni 1380-as (2001-2002) és az 1395-ös (2016-2017) naptári év adatait (5. és 6. táblázat), akkor a következő derül ki. 


\section{Külïgyi Szemle}

5. táblázat ${ }^{20}$

A gyárak számának eloszlása méret és tulajdonviszony alapján az 1380-as naptári évben (2001-2002)

\begin{tabular}{|l|c|r|r|r|r|r|r|r|}
\hline Méret & \multicolumn{2}{|c|}{$\begin{array}{c}10-49 \\
\text { alkalmazott }\end{array}$} & \multicolumn{2}{c|}{$\begin{array}{c}50-99 \\
\text { alkalmazott }\end{array}$} & \multicolumn{2}{c|}{$\begin{array}{c}100-\text { nál több } \\
\text { alkalmazott }\end{array}$} & \multicolumn{2}{c|}{ Összesen } \\
\hline $\begin{array}{l}\text { Tulajdon } \\
\text { jellege }\end{array}$ & Számuk & $\%$ & Számuk & $\%$ & Számuk & $\%$ & Számuk & $\%$ \\
\hline Magán & 7852 & 97 & 1146 & 92 & 1205 & 74 & 10.203 & 93 \\
\hline Állami & 258 & 3 & 103 & 8 & 424 & 26 & 784 & 7 \\
\hline Összesen & 8110 & 100 & 1249 & 100 & 1629 & 100 & 10.987 & 100 \\
\hline
\end{tabular}

\section{6. táblázat ${ }^{21}$}

A gyárak számának eloszlása méret és tulajdonviszony alapján az 1395-ös naptári évben (2016-2017)

\begin{tabular}{|l|r|r|r|r|r|r|r|r|}
\hline Méret & \multicolumn{2}{|c|}{$\begin{array}{c}10-49 \\
\text { alkalmazott }\end{array}$} & \multicolumn{2}{c|}{$\begin{array}{c}50-99 \\
\text { alkalmazott }\end{array}$} & \multicolumn{2}{c|}{$\begin{array}{c}100-\text { nál több } \\
\text { alkalmazott }\end{array}$} & \multicolumn{2}{c|}{ Összesen } \\
\hline $\begin{array}{l}\text { Tulajdon } \\
\text { jellege }\end{array}$ & Számuk & $\%$ & Számuk & $\%$ & Számuk & $\%$ & Számuk & $\%$ \\
\hline Magán & 24.813 & 99 & 3282 & 98 & 2847 & 95 & 30.942 & 98 \\
\hline Állami & 169 & 1 & 51 & 2 & 148 & 5 & 368 & 2 \\
\hline Összesen & 24.982 & 100 & 3333 & 100 & 2995 & 100 & 31.310 & 100 \\
\hline
\end{tabular}

Az iráni gyárak nagy része kisvállalkozás volt, legfeljebb tíz embert alkalmaztak. Ebben a szegmensben a tulajdonosi szerkezet alig változott. Ha azonban a 100-nál több embert foglalkoztató gyárakat nézzüik, látható, hogy azok közüil egyre több került magántulajdonba. Míg 2002-ben a nagyüzemek 26 százaléka (többnyire olyan kulcsfontosságú iparágak, mint az autó- és az acélipar) közvetlenül az állam, az önkormányzatok vagy a félig állami vállalatok tulajdonában volt, 2017-re az arányuk 5 százalékra csökkent.

20 Forrás: Iranian Statistical Office, 2002, 317 - Diagram 8-8.

21 Forrás: Presidency of the I.R.I. Plan and Budget Organization, 2021, 317 - Diagram 8-8. 


\section{Olajszektor}

Az iráni gazdaságnak nincs még egy olyan ágazata - talán a mezőgazdaság kivételével -, amely olyan nagy hatást gyakorolt volna Irán jelenlegi történelemére, mint az olaj. Nem csupán nyersanyag, hanem az iráni függetlenség szimbóluma, valamint a nemzet fejlesztési programjainak a motorja és pénzügyi forrása volt. A legfrissebb statisztikai adatok szerint az olajszektornak a bruttó hazai termékhez viszonyított aránya a hetvenes évek eleji kb. 60 százalékról az ötödére csökkent. Az olajszektor mégis a meghatározó tényezóje maradt az az ország gazdaságának. Az iráni 1397-es naptári év (2018-2019) végén az ágazat termelése a mezőgazdaságénak közel a háromszorosát tette ki, és majdnem elérte az iparét. Az alábbi ábra az 1388-as iráni naptári évtől (azaz 2009. március 21-től) 1396-ig (2018. március 20-ig) számított nettó olajexport alakulását mutatja. Valószínúsíthető, hogy Donald Trump maximum pressure politikája következtében ez jelentős mértékben csökkent, amit tükröz az olajszektor majdnem 20 százalékos visszaesése is. Sajnos, az iráni hatóságok nem publikáltak erre vonatkozóan pontos adatokat, így csupán 2018-ig tudjuk szemléltetni a nyersolaj nettó exportját.

\section{6. ábra ${ }^{22}$}

A nyersolaj nettó exportja, 2010-2018 (1000 hordó)

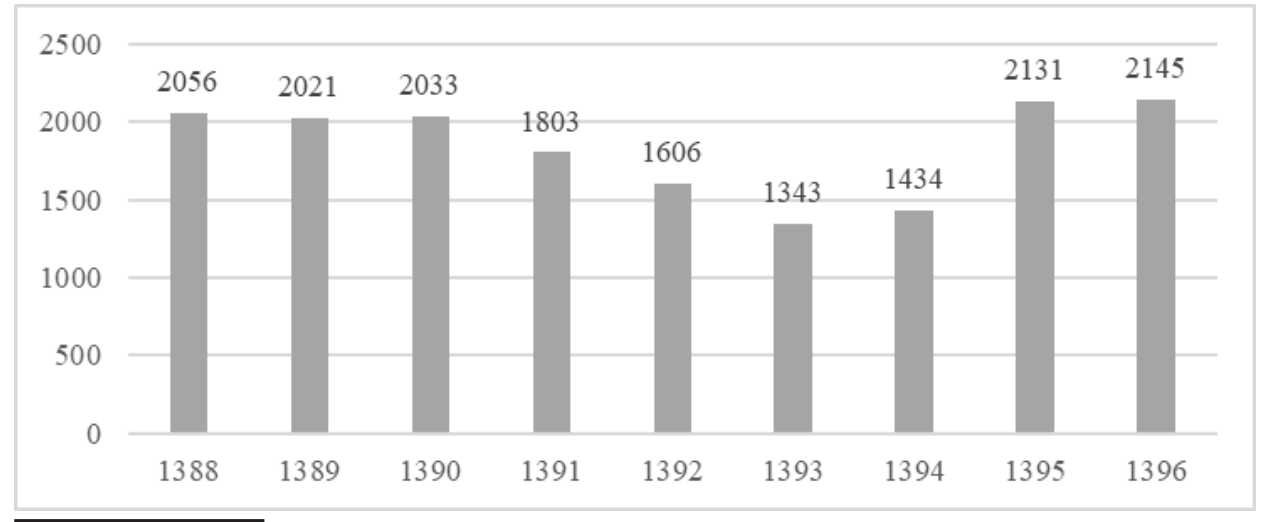

22 Forrás: Central Bank of the Islamic Republic of Iran, 2020a, 58. o. 


\section{Külïgyi Szemle}

Az olajszektornak az iráni gazdaságra gyakorolt valódi befolyását nehéz megbecsülni, és a közgazdászok körében ez a kérdés heves viták tárgya (ld. Dargáhi, 2018, 22. o.). Habár a GDP-hez viszonyítva ez az ágazat Iránban lényegesen kisebb arányt tesz ki, mint a régió más járadékgazdaságaiban, az elmúlt öt naptári évben az olaj értékesítéséből származó jövedelem a teljes állami költségvetés több mint egyharmadát, egyes években majdnem 50 százalékát adta!

\section{7. táblázat ${ }^{23}$}

Az olajból származó bevétel a teljes iráni költségvetésben (1000 milliárd riál)

\begin{tabular}{|l|c|c|c|c|c|c|}
\hline Iráni költségvetési év & 1392 & 1393 & 1394 & 1395 & 1396 & 1397 \\
\hline Összes állami bevétel & 1329,50 & 1609,50 & 1737,30 & 2203,50 & 2598,90 & 2947,7 \\
\hline $\begin{array}{l}\text { Olajból és ahhoz } \\
\text { kapcsolódó termékból } \\
\text { származó bevétel }\end{array}$ & 609,40 & 629,20 & 670,40 & 793,80 & 919,20 & 1105,4 \\
\hline $\begin{array}{l}\text { Az olajból származó } \\
\text { bevétel százalékban }\end{array}$ & $45,83 \%$ & $39,09 \%$ & $38,59 \%$ & $36,02 \%$ & $37,67 \%$ & $37,5 \%$ \\
\hline
\end{tabular}

Az olajból származó jövedelem magas aránya ellenére még mindig kisebb Iránnak a Közel-Kelet aranyától való függősége, mint a hetvenes évek közepén volt, amikor az az összes állami bevétel közel 80 százalékát tette ki. Egy másik pozitív jel, hogy az 1393-as naptári évben (2014. március-2015. március) az adókból eredő bevételek már meghaladták az olajból származó jövedelmet. Noha a forradalom egyik célja (például az iráni iparvédelmi és fejlesztési törvényben és számos más fejlesztési programban meghatározottak szerint), az olajfüggőség teljes felszámolása nem valósulhat meg, azonban erős törekvés mutatkozik annak csökkentésére.

A 2019-2020-as adatokból az is kitúnik, hogy az 1397-es iráni naptári évben (2018-2019) tovább növekedtek az olajbevételek. Ez elég ellentmondásosnak tűnik annak fényében, hogy az olajszektor GDP-arányos bezuhanása jelentős volt. Ennek egyik oka az iráni belső

23 Forrás: Central Bank of the Islamic Republic of Iran, 2021. 72. o., 41. ábra. 
elszámolási rendszerre vezethető vissza, amely az olajbevételeket az államiaktól különválasztja, és egy külön alapba csatornázza. A másik az, hogy Iránnak a trumpi szankciók megkerülésével, egyéb módon sikerült értékesítenie az olajkészleteit. A rendelkezésre álló adatokból azonban nem tudunk egyértelmú választ adni erre a kérdésre.

Az ötvenes évektől, azaz a Moszaddegh-éra ${ }^{24}$ óta az olajszektort nagyrészt az állam uralja, és az közvetlenül a kőolaj-minisztérium alá tartozik. Amikor a forradalom után a nagy államosítási hullámok elkezdődtek, az ágazat legnagyobb vállalatai (Iráni Nemzeti Olajtársaság, Iráni Nemzeti Gázvállalat, Iráni Nemzeti Olajtermék-forgalmazó Vállalat, Nemzeti Petrolkémiai Vállalat) már központi ellenórzés alatt álltak. A minisztérium közvetlenüil ellenőrzi azokat, s így többé-kevésbé az egész szektort (Islamic Republic of Iran, Ministry of Petroleum, 2021).

A vállalatok közül a legjelentősebb az Iráni Nemzeti Olajtársa ság, amelyet 1951-ben alapítottak, és azóta is kulcsszerepet játszik az ország szénhidrogéniparában. Tevékenységei közé tartozik a „feltá rás, fúrás, gáz- és olajtermelés, kutatás és fejlesztés, olaj, gáz és olajtermékek finomítása és forgalmazása, valamint az export”, és a cég 2018-as éves jelentése szerint „a második legnagyobb olajtársaság a világon" (N.I.O.C., 2018, 2. o.).

A négy óriásvállalaton kívuil számos kisebb is létezik, amelyek története részben a sah idejére nyúlik vissza. Ilyen például a különböző olajtermékeket (köztük motorolajat és fagyállót) gyártó Behran Olajtársaság. A céget 1963-ban, Exxon-licencként alapították, és a forradalomig az amerikai vállalatnak 25 százalékos részesedése volt a társaságban, amely később a Mosztazefán és Dzsánbazán Alapít ványhoz ${ }^{25}$ kerüilt (Rahmánzáde Heravi, 2019, 355. o.). Egy másik példa

24 Mohammed Moszaddegh Irán miniszterelnöke 1951 és 1953 között. Nevéhez köthető az ország olajszektorának az államosítása, amely akkoriban többségében külföldi tulajdonban volt. 1953-ban az angol és amerikai titkosszolgálatok közre múködésével zajlott puces buktatta meg.

25 A Közel-Kelet egyik legnagyobb gazdasági alapítványa, Iránban az egyik legjelen tősebb gazdasági szereplő, közvetlenül Ali Khamenei irányítása alatt áll. (Miköz ben a moszlazefán va dzsánbazán jelentése „elesettek és hadirokkantak”.) 


\section{Külïgyi Szemle}

az 1976-ban alapított, állami tulajdonban lévő Esfahan Olajfinomító Vállalat, amely az összes, olajjal kapcsolatos iráni termék 23 százalékát állítja elő (Esfahan Refinery, 2021). Bár e vállalatok többnyire állami vagy félállami tulajdonban vannak, az utóbbi 10 évben már a magánszektor is némi szerephez jutott, és néhánynak a részvényeit „igazságossági részvény” formájában osztották szét, noha kevés sikerrel (Rahmánzáde Heravi, 2019, 350. o.).

\section{Mezőgazdaság}

Habár a legfrissebb statisztikai adatok szerint Irán mezőgazdasága az ország teljes bruttó nemzeti jövedelmének mindössze 6,7 százalékát teszi ki, a stratégiai jelentősége aligha hagy kétséget. Az olajszektor mellett ez az ágazat formálta át a leginkább a 20. századi iráni politikát. Míg az olajipar a modernitás, a nemzeti függetlenség és a haladás, addig a mezőgazdaság a hagyomány szimbóluma volt. A hatvanas és a hetvenes évek legbefolyásosabb iráni gondolkodói - Ali Shariati és Jalal Al-e Ahmad - a hagyományos, vidéki gazdálkodást a modern, nyugati és gépesített élelmiszer-elóállítási módszerek ellenpontja ként ábrázolta mint lehetséges alternatívát (pl. Lenze, 2008, 123. o.). A második világháború után az ágazat, amelynek a szerkezete még a hatvanas években is feudális jellegű volt (ld. Bobek és Puls, 1964), a különböző politikai csoportok közötti harctérré változott.

Míg a liberálisok az amerikai mintájú földreformot és a magánvállalatok létrehozását sürgették, addig a kommunista Tudeh Párt a kollektív gazdaságok létrehozásában látta a megoldást, ahogy az a Szovjetunióban történt. Ezeket a reformtörekvéseket a hagyományos földtulajdonosok ellenezték - márpedig a hatvanas évekig ők uralták az iráni parlamentet. Mohammad Reza Pahlavi hatvanas évek köze pén kezdődött „fehér forradalmának” kellett volna az iráni félfeudális mezőgazdaságot a modernitás felé lendítenie. A program nagyszabású földreformot irányzott elő, a régi tulajdonosok földjeinek egy része független gazdákhoz került, és számos élelmiszer-előállító gyárat lé tesítettek (Katouzian, 1992, a 303. oldaltól; Majd, 1987). 


\section{7. ábra ${ }^{26}$}

Az iráni mezőgazdaság növekedési rátája 1960 és 2017 között (\%)

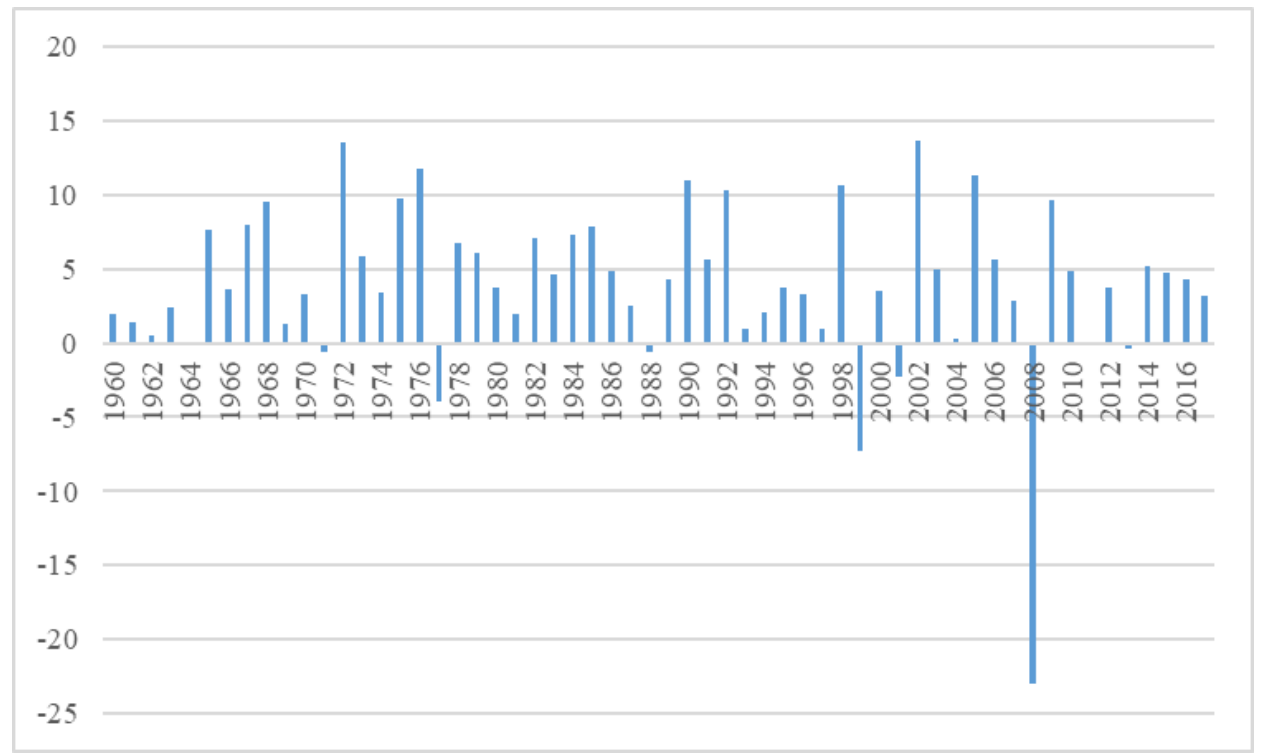

Az iráni mezőgazdasági szektor kapcsán hosszú távon azt láthat juk, hogy a hatvanas évek közepén végbement reformok lendületet adtak az ágazatnak, és az az iszlám forradalom után is folyamatos növekedést mutatott, míg az új rendszer többé-kevésbé a régi struktúrákra építkezett. Nagyjából ugyanez a következtetés vonható le, ha a mezőgazdasági földterületek méretét és a termelési mutatót hasonlítjuk össze (8. ábra).

A statisztikák alapján láthatjuk, hogy míg a művelt földterületek mennyisége körülbelül 10 százalékkal csökkent 1989 óta, a termelési mutató majdnem a háromszorosára nőtt. Ezek az arányok lehetővé tették, hogy a mezőgazdasági szektor növekedése az adott időszakban lépést tudjon tartani a népesség növekedésével. ${ }^{27}$

26 Forrás: Central Bank of the Islamic Republic of Iran, 2020b, 21. és 22. táblázat. 27 1979-ben Irán népessége 37,24 millió, 2019-ben már majdnem 83 millió fő volt. 


\section{Külïgyi Szemle}

8. ábra ${ }^{28}$

A művelés alatt álló földterület és a termelési mutató

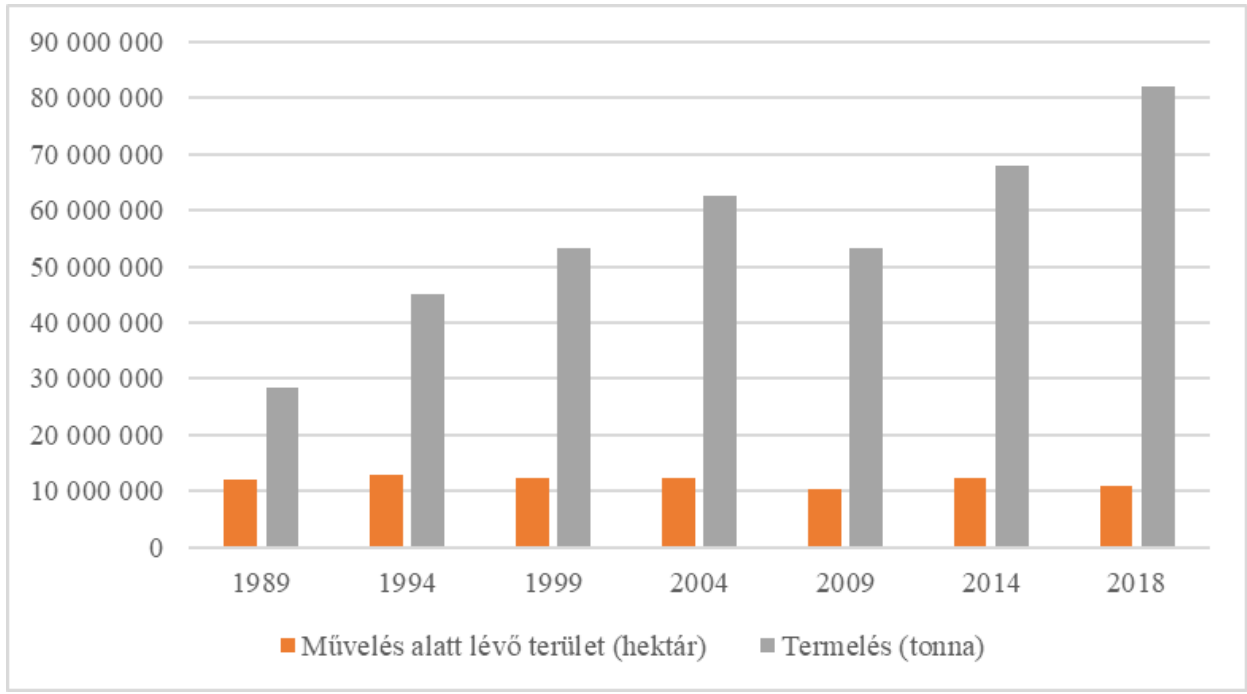

Az iráni mezőgazdasági ágazatnak ennek ellenére komoly kihívásokkal kell szembenéznie. A múltban már többször megfogalmazott, és a jelenlegi fejlesztési tervnek (Madzslesz-e Surá-je Eszlámi, 2017) szintén egyik sarkalatos pontját jelentő önellátás még távol van. Az 1396-os iráni naptári évben (2017. március-2018. március) az öszszes behozatal 14 százaléka élelmiszertermék (és haszonállat) volt, amelynek 45 százalékát gabonafélék és ahhoz kapcsolódó termékek tették ki. (Central Bank of the Islamic Republic of Iran, 2020a, 48. o., táblázat). Ezenfelüil az ágazat nem is múködik elég hatékonyan: míg a GNI-nek mindössze a 6,7 százalékát teszi ki, az ország elektromos áramának 14 százalékát fogyasztja, és az összes vízfogyasztás közel 70 százalékáért felelős (Central Bank of the Islamic Republic of Iran, 2020a, 66. o.; Iranian Statistical Office, 2020, 349. o.).

28 Forrás: az Iráni Földművelésügyi Minisztérium éves jelentései. 
A mezőgazdaság legnagyobb kihívása nem feltétlenuil ágazatspecifikus, hiszen a jelentős finanszírozási nehézségek az egész iráni gazdaságot érintik. A drága hitelek és a külföldi tőke bevonási lehetőségének a korlátai miatt az agrárvállalatok krónikus tőkehiányban szenvednek, ennek következtében a mezőgazdasági létesítmények korszerútlenek, a géppark pedig elavult (Rahmánzáde Heravi, 2019, 387. o.). Mohammed Rahmánzáde Heravi becslései szerint támogatások nélkül az állattenyésztô cégek mintegy 30 százaléka csődbe menne (Rahmánzáde Heravi, 2019, 390. o.). A többi kihívás már inkább ágazatspecifikusnak tekinthető. Ilyen például az egyes területeken az éghajlatváltozás miatt kialakult krónikus vízhiány (Szálkai és Szabó, 2021), illetve a döntéshozóknak a pénzügyi problémák kezelése és az elavult jogszabályok felülbírálása kapcsán megmutatkozó tehetetlen sége (Dunjá va Iqtișzād, 2018), vagy a kis földek eladásának a nehézsé gei (Islamic Rebublic News Agency, 2015).

A kihívások ellenére kijelenthető, hogy az Al-e Ahmad mủveiben idilli helyszínként megjelenített vidéki Irán folyamatosan teret veszít, és egy-két évtized múlva örökre megszűnik. Az 1979-es forradalom nem hátráltatta a sah adminisztrációjának az egyik legnagyobb projektjét, sőt éppen ellenkezőleg történt: megtartotta a mezőgazdasági átszervezés alapvető struktúráját, és az haladt tovább a modernizáció útján (Rahmánzáde Heravi, 2019, 389. o.). Ennek igazolására elég, ha a traktorok és kombájnok éves árbevételének a növekedését nézzüik meg (Iranian Statistical Office, 2020, 256. o.).

\section{Összegzés}

Tanulmányunkban Irán jelenlegi gazdasági állapotát és az elmúlt tíz húsz év liberalizációs tendenciáit vettük górcső alá. Úgy látjuk, hogy a nemzetközi elszigeteltség ellenére az ország politikai döntéshozói a nemzetközi gyakorlatot követik. A washingtoni konszenzus egyér telműen „rányomta a bélyegét” a döntéshozók adózással és magántulajdonnal kapcsolatos hozzáállására, és a tendenciák alapján valószínútlennek tartjuk, hogy ez Ebrahim Raiszi kabinetje alatt változni fog. 


\section{Külïgyi Szemle}

Egyértelmủen kijelenthetjïk, hogy a gazdasági liberalizációra szuikség volt, és az összességében eredményesnek bizonyult. A koráb bi állami vállalatok privatizációjával kapcsolatos intézkedések jelentős mértékben segítették a gazdaság növekedését, és a legtöbb esetben nagyobb hatékonyságot eredményeztek. Különösen a szolgáltatási szektorban és azon belül is a szállítási és kommunikációs szegmens ben tapasztalható nagyütemú növekedés.

Ennek ellenére megállapítható, hogy a sok liberalizációs intéz kedést rendszertelenül vezették be, ráadásul az iráni gazdasági re alitások figyelembevétele nélkül. A hatóságokat túlterhelték az új adminisztratív feladatok és a jogszabályok hiányosságai (például a szabadkereskedelmi övezetek tekintetében), és ez sok bizonytalanságot okozott termelói szinten. Ami a privatizációs folyamatot illeti, az etatistaalkotmány egyes részeinek újraértelmezése segítő szándékú volt, azonban meggondolatlanul hajtották végre azokat. Úgy tủnik, a döntéshozók csak a „százalékot” látták „az állami szektorban”, amelyet bármi áron, de csökkenteni kellett. A Sherman trösztellenes törvény egyes részeinek a szó szerinti átvétele sem az üzleti kultúra, sem a vezetỏi kompetencia hiányát nem vette figyelembe, miközben mindkettőre nagy szükség van ahhoz, hogy egy cég versenykörnyezetben is működjön. Ezért a privatizációs folyamat több fontos területen (pl. a banki és biztosítási területen) „félúton elakadt”.

Mindennek az ára az egyszerủ polgár számára is jól érzékelhető: hosszabb várakozási idő a buszmegállóban; rosszabb minőségú élelmiszer - mivel az élelmiszer-termelők korlátozottan jutnak hitelhez, így nem tudják korszerủsíteni a gyáraikat -; évente egy városnyi ember hal meg közúti balesetek következtében, és így tovább. Ezeket a problémákat pedig naprakész jogszabályokkal, nagyobb átláthatósággal, hatékony vállalatirányítással és illetékes szabályozó testületekkel megfelelően orvosolni lehetne.

Részben éppen a piaci liberalizáció segítette az iráni gazdaság jelenlegi felépítését, amit sem a Trump-adminisztráció maximum pressure politikája, sem a Covid19-krízis nem tudott megroppantani. De a talpra állás nehézkes lesz, és a Raiszi-adminisztrációnak minden 
erejét be kell vetnie, és rövid távon akár fájdalmas strukturális refor mokat is be kell vezetnie, ha hosszú távon biztosítani szeretné sok iráni álmát: kitörni a fejlődő országok sorából, és a Közel-Kelet Japánjává válni.

\section{Irodalomjegyzék}

Abrahamian, Ervand (2018). A History of Modern Iran. Cambridge, New York, NY, Port Melbourne, Újdelhi és Szingapúr: Cambridge University Press.

Abrismi, Hamíd, Dorudiján, Ḥuszein és Nuri, Mehdi (2016-2017). Csálishá je Eqteszádi-je Irán [Az iráni gazdaság kihívásai]. Teherán: Entesárát Nur-e 'Ilm.

Atrkar Roshan, Sedigheh, Shirinbakhsh, Shamsollah, Esfandyar, Maryam és Doroudian, Hossein (2015). The Effect of Privatization on the Performance of the Tehran Bus Lines (With Emphasis on the BRT System). Journal of Urban Economics and Managemenl, 3(10), 59-76. A letöltés ideje: 2021. augusztus 12. https:/iueam.ir/browse.php?mag

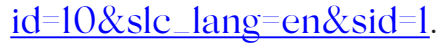

Birdsall, Nancy; Fukuyama, Francis (2011). The Post Washington Consensus Development - After the Crisis. Foreign Affairs, $90(2)$. A letöltés ideje: 2021. augusztus 12. https://si.stanford.edu/publications/the postwashington consensus.

Bobek, Hans (1967). Iran. Probleme eines unlerentwickelten Landes alter Kullur: Frankfurt am Main: Moritz Diesterweg.

Bobek, Hans és Puls, Willi Walter (1964). Iran: Probleme eines unlerentwickelten Landes alter Kultur. Frankfurt am Main: Moritz Diesterweg.

Burawoy, Michael (1994). Why Coupon Socialism Never Stood a Chance in Russia: The Political Conditions of Economic Transition. Politics and Sociely, 22(4), 585-594.

Central Bank of the Islamic Republic of Iran (2020a). Kholásze-je Tahav volát-e Eqteszád-e Kesvar 1396 [Az ország gazdasági fejlődésének összefoglalása, 1396 (2017-2018)]. A letöltés ideje: 2021. augusztus 12. https:/Www.cbi.ir/page/18957.aspx. 


\section{Külïgyi Szemle}

Central Bank of the Islamic Republic of Iran (2020b). National Accounts 1338-1393. A letöltés ideje: 2021. augusztus 12. https://www.cbi.ir/ category/EconomicReport fa.aspx.

Central Bank of the Islamic Republic of Iran (2020c). National Accounts of Iran. A letöltés ideje: 2021. augusztus 12. https://www.cbi.ir/categorv/ EconomicReport_fa.aspx.

Central Bank of the Islamic Republic of Iran (2020d). National Balance Sheets 1396. A letöltés ideje: 2021. augusztus 12. https://www.cbi.ir/ category/EconomicReport fa.aspx.

Central Bank of the Islamic Republic of Iran (2021). Kholásze-je Tahavvolát-e

Eqteszád-e Kesvar 1396 [Az ország gazdasági fejlődésének összefoglalása, 1397 (2018-2019)]. A letöltés ideje: 2021. augusztus 12. https://www.cbi. ir/page/20897.aspx.

Central Insurance of the Islamic Republic of Iran (2019). The Effects of the Sanctions on Iran's Insurance Industry.

Constituteproject.org (2021). Iran (Islamic Republic of)'s Constitution of 1979

with Amendments Through 1989. A letöltés ideje: 2021. augusztus 27. https://www.constituteproject.org/constitution/Iran_1989.pdf?lang=en.

Cseh Balázs, Varga József és Bánkuti Gyöngyi (2019). The Women in the Labour Market: Aspects of Demography and Work Based in the MENA Countries. In Balázs Judit, Cseh Balázs és Varga József (szerk.), Kilekinlés az iszlám világ 21. századi politikai, gazdasági és pénzügyi viszonyaira $(12-27$. o.)

Csicsmann, László (2021). A szankciók mint a nyomásgyakorlás eszközei a nemzetközi kapcsolatokban: a Közel-Kelet és Irán esete. Külügyi Szemle. $20(3), 80-112$.

Dargáhi, Hasan. (2018). Tahlil-e Csálishá-je Rusd-e Eqteszádi-je Irán. Rujkard Ulgu-je Eqteszádszandzsi Kalán. [Az iráni gazdasági növekedés kihívásai. Makrogazdasági modell megközelítés]. Faszlnáme IImi Puzsuhesi, 22(7), 3-41.

De Souza Rodrigues Cabral, Caroline, Dornigg, Jürgen, Kubli, Daniel és Staib, Daniel (2020). Sigma 4/2020: World Insurance: Riding out the 2020 Pandemic Storm. Swiss Re Instilute. A letöltés ideje: 2020. december 3. https:/www.swissre.com/institute/research/sigmaresearch/sigma-2020-04.html.

Dobbs, Richard, Hatami, Homayoun, Allas, Tera, Arab, Saba és Mahtafar, Arsalan (2016). Iran: the \$1 Trillion Growth Opportunity? 
McKinseydrCompany. A letöltés ideje: 2021. augusztus 16. https:/en.inif. ir/documents/40462/302234/2016.pdf/8e6dafac-e6c8-5800-b6c4b3f967c3a953?t $=1577084952000$.

Dunjá va Iqtișzād (2017). Qānun ḍidd-i Trast-i Širman Tașvỉb šud [Elrendelték a trösztellenes Sherman-törvényt]. https://donya-e-eqtesad.com/\%D 8\% A 8\%D 8\% AE \% D 8 B 4\% $8 \%$ A $7 \%$ D $9 \% 82 \%$ D $8 \%$ A A \% D $8 \%$ B 5\% D $8 \%$ A $7 \%$ D $8 \%$ A F36/1106870-\%D 9\%82\%D 8\% A 7\% D 9\% 86\% D 9\% 88\%D 9\% 86-

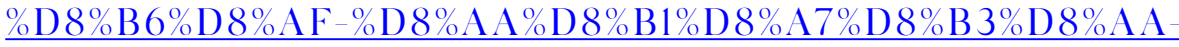

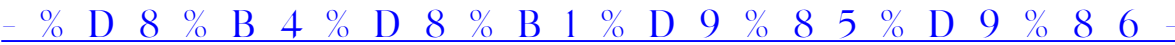
$\% \mathrm{D} 8 \% \mathrm{AA} \% \mathrm{D} 8 \% \mathrm{~B} 5 \% \mathrm{D} 9 \% 88 \% \mathrm{DB} \% 8 \mathrm{C} \% \mathrm{D} 8 \% \mathrm{~A} 8-\% \mathrm{D} 8 \% \mathrm{~B} 4 \% \mathrm{D} 8 \% \mathrm{AF}$.

Dunjá va Iqlișzād (2018). Kalid-e hall-e csáleshá-je kesávarzi csiszt? [Mi a megoldás mezőgazdaság kihívásaira?]. https:/donya-e-eqtesad. com/\% $/ \%$ A $8 \% \mathrm{D} 8 \% \mathrm{AE} \% \mathrm{D} 8 \% \mathrm{~B} 4-\% \mathrm{D} 8 \% \mathrm{B3} \% \mathrm{D} 8 \% \mathrm{~A} 7 \% \mathrm{DB} \% 8 \mathrm{C} \% \mathrm{D} 8 \% \mathrm{AA}$ \% D 8\% A E \% D 9\% 8 8\% D 8\% A 7\% D 9\%86-62/3428256\% DA \% A 9 D 9\% 84\% D B \% 8 C \% D\% A F-\% D 8\% A D \% D 984 \%DA $\% 86 \%$ D $8 \%$ A7\%D9\%84\%D 8\%B 4-\%D 9\%87\%D8\%A7\%DB\%8C-

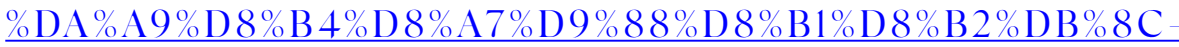
$\% \mathrm{DA} \% 86 \% \mathrm{DB} \% 8 \mathrm{C} \% \mathrm{D} 8 \% \mathrm{B3} \% \mathrm{D} 8 \% \mathrm{AA}$.

Esfahan Refinery (2021). Front Page. A letöltés ideje: 2021. augusztus 16. https://www.eorc.ir/front-page/.

Eslam.de (2006). Verfassung der Islamischen Republik Iran. A letöltés ideje: 2019. július 17. http://www.eslam.de/manuskripte/verfassung_iri/ praeambel.htm\#Einleitung.

European Commission (2020). Tourism Statistics - Annual Results for the Accommodation Sector. Euroslat. A letöltés ideje: 2021. augusztus 27. https:/ec.europa.eu/eurostat/statistics-explained/ index.php?title =Tourism statistics _ annual results for the accommodation sector.

Fukuyama, Francis (2004). State-Building: Governance and World Order in the 21s/ Century. Ithaca, NY: Cornell University Press.

Gefahrenstellen.de (2021). Gefahrenstellen auf Straßen erkennen und melden. A letöltés ideje: augusztus 16. https:/www.gefahrenstellen.de/. Hásemi, Sóleh (2018-2019 [1397]). Bime dar fiqh, hoquq va dzsáme-je emruz [Biztosítás az iszlám jogban, a világi jogban és a mai társadalomban]. Teherán: Madzsd.

IMF eLIBRARY (2018). Islamic Republic of Iran:2018 Article IV Consultation Press Release; Staff Report; and Statement by the Executive Director 


\section{Külïgyi Szemle}

for the Islamic Republic of Iran. A letöltés ideje: 2020. április 16. https:// www.elibrarv.imf.org/view/journals/002/2018/093/002.2018.issue093-en.xml.

International Labour Organization (2008). Iran (Islamic Republic of). A letöltés ideje: 2021. augusztus 12. https://ilo.org/dvn/natlex/natlex4. detail?p_lang $=$ en\&p_isn=91848\&p_country=IRN\&p_count $=168$.

InternationalMonetaryFund (2019). Saudi Arabia:2019ArticleIVConsultation

Press Release; and Staff Report. A letöltés ideje: 2021. augusztus 12. https:// www.imf.org/en/Publications/CR/Issues/2019/09/09/Saudi-Arabia2019-Article-IV-Consultation-Press-Release-and-Staff-Report-48659.

International Monetary Fund (2020). World Economic Outlook, April 2020: The Great Lockdown. A letöltés ideje: 2021. augusztus 12. https:/www. imf.org/en/Publications/WEO/Issues/2020/04/14/World-EconomicOutlook-April-2020-The-Great-Lockdown-49306.

International Monetary Fund (2021). Islamic Republic of Iran. A letöltés ideje: 2021. augusztus 12. https://www.imf.org/en/Countries/IRN\#countrydata. Iqtisad Online (2016). Moskelát-e hákim bar nizám-e bánki [A bankrendszer kulcskérdései]. A letöltés ideje: augusztus 16. https://www.eghtesadonline.com/\%D 8\% A 8\%D 8\%AE \% $8 \%$ B 4\%D $8 \%$ A $8 \% \mathrm{D} 8 \%$ A $7 \% \mathrm{D} 9 \% 86 \% \mathrm{DA} \%$ A $9-5 / 144151-\% \mathrm{D} 9 \% 85 \% \mathrm{D} 8 \% \mathrm{~B} 4 \% \mathrm{DA}$ \% A9\%D9\%84\%D8\% A7\%D8\%AA-\%D8\%AD\%D8\% A7\%DA\%A9\%D9\%85\% D 8\% A 8\% D 8\% B 1-\% D 9\% 86\% D 8\% B 8\% D 8\% A $7 \%$ D $9 \% 85$ $\% \mathrm{D} 8 \%$ A $8 \% \mathrm{D} 8 \% \mathrm{~A} 7 \% \mathrm{D} 9 \% 86 \% \mathrm{DA} \% \mathrm{~A} 9 \% \mathrm{DB} \% 8 \mathrm{C}$.

Iran Chamber of Commerce, Industries, Mines \& Agriculture (2018). Statis tical Yearbook 1397. Iran-Greece Chamber of Commerce. A letöltés ideje: 2021. augusztus 12. http://www.igecim.com/NewsPost.aspx?l=2\&Id=57.

Iranian Statistical Office (2002). Sālnāma-yi Āmār 1380 [Statisztikai évkönyv 2001-2002]. https://ssis.sci.org.ir/\%D8\%B3\%D8\%A7\%D9\%84\%D9\%86\% D8\%A7\%D9\%85\%D9\%87-\%D8\%A2\%D9\%85\%D8\%A7\%D8\%Bl\%DB\%8C$\% \mathrm{DA} \% \mathrm{~A} \% \mathrm{D} 8 \% \mathrm{~B} 4 \% \mathrm{D} 9 \% 88 \% \mathrm{D} 8 \% \mathrm{B11380}$.

Iranian Statistical Office (2020). Salnama-yi Ámār 1396 [Statisztikai évkönyv 2017-2018]. https:/www.amar.org.ir/news/ID/102 84/\% D 8\% A 7\% D 9\%86\% D 8\% A A D 8\%B 4\%D 8\% A 7\% D 8\%B1\%D 9\%86\%D 8\%B 3\%D 8\%AE\% D 9\%87-\%D 8\% A7\%D 9\% 84\%DA\% A9 \% D $8 \%$ A $\%$ D $8 \%$ B1\%D $9 \% 88 \% \mathrm{D} 9 \% 86 \% \mathrm{DB} \% 8 \mathrm{C} \% \mathrm{DA} \% \mathrm{~A} 9 \% \mathrm{DB} \% 8 \mathrm{C}-$ \% D 8\%B 3\%D 8\%A7\%D 9\%84\%D 9\% 86\%D 8\% A7\%D 9\% 85\%D 9\% 87$\%$ D $8 \%$ A $7 \%$ D $9 \% 85 \%$ D $8 \%$ A $7 \%$ D $8 \%$ B 1\% D B \% 8 C\%DA\%A9\%D8\%B4\%D9\%88\%D8\%B1-\%D8\%B3\%D8\%A7\%D9\%841396. 
Islamic Rebublic News Agency (2015). Zaminhá-je khord máne-je to'szia kesávarzi eqteszádi dar Khorászán somáli [A mikroföldek akadályozzák a mezőgazdaság fejlődését Észak-Khoraszánban]. A letöltés ideje: augusztus 16. https://www.irna.ir/news/81467514 \%D $8 \%$ B2\%D $9 \% 85 \% \mathrm{DB} \% 8 \mathrm{C} \% \mathrm{D} 9 \% 86-\% \mathrm{D} 9 \% 87 \% \mathrm{D} 8 \% \mathrm{~A} 7 \% \mathrm{DB} \% 8 \mathrm{C}-$ \% $8 \%$ AE $\%$ D $8 \%$ B1\%D 8\%AF-\%D 9\% 85\%D 8\%A7\%D 9\%86\%D 8\%B9\% D 8 A A \% D $\% 88 \%$ D 8\%B3\%D 8\%B9\%D9\%87-\%D9\%83\%D 8\%B 4\% $8 \%$ A $7 \%$ D $9 \% 88 \%$ D 8\%B1\%D $8 \%$ B2\%DB\% 8C-\%D $8 \%$ A $7 \%$ D $9 \% 82 \%$ D 8\%A A\%D 8\%B5\%D 8\%A7\%D 8\%AF\%DB\%8C-\%D 8\%AF\%D 8\%B1\% D 8\% A E \% D 8 B 1\% D 8\% A $7 \%$ D 8\% B 3\% D 8\% A 7\% D 9\% 86\% $8 \% \mathrm{~B} 4 \% \mathrm{D} 9 \% 85 \% \mathrm{D} 8 \% \mathrm{~A} 7 \% \mathrm{D} 9 \% 84 \% \mathrm{DB} \% 8 \mathrm{C}$.

Islamic Republic of Iran, Ministry of Petroleum (2021). Home. A letöltés ideje: augusztus 16. https://en.mop.ir/Portal/Home/.

Iszlámi, Mohammad Reza (2019). Naqdi bar Ketáb „Deghdeghe-je Irán” va Negáhi-je be Nazm-e Zehni-je Muhamad Fázili [Az „Irán aggodalma" címủ könyv kritikája és a Muhamad Fázili érvelésével kapcsolatos nézet]. Khabaronline. A letöltés ideje: 2021. augusztus 12. https://www.khabaronline.ir/news/1293270/\%D9\%86\%D9\%82\%D8\% AF\%DB\%8C-\%D8\%A8\%D8\%B1-\%DA\%A9\%D8\%AA\%D8\%A7\%D8\%A8$\%$ D $8 \%$ A F \% D $8 \%$ B A \% D $8 \%$ A F \% D $8 \%$ B A \% D $9 \% 87$ $\%$ D 8\% A 7\% D B \% 8C \% D 8\% B 1\% D 8\% A 7\% D 9\% 86-\%D 9\%8 8\% D9\%86\%DA\%AF\%D8\%A7\%D9\%87\%DB\%8C-\%D 8\%A8\%D9\%87\% D9\%86\%D 8\%B8\%D 9\%85-\%D8\%B $\%$ D9\%87\%D9\%86\%DB\%8C\begin{tabular}{llllllllllllllllllllllll}
$\%$ & $\mathrm{D}$ & 9 & $\%$ & 8 & 5 & $\%$ & $\mathrm{D}$ & 8 & $\%$ & $\mathrm{~A}$ & $\mathrm{D}$ & $\%$ & $\mathrm{D}$ & 9 & $\%$ & 8 & 5 & $\%$ & $\mathrm{D}$ & 8 & $\%$ & $\mathrm{~A}$ & $\mathrm{~F}$ \\
\hline
\end{tabular} \% $9 \% 81 \% \mathrm{D} 8 \% \mathrm{~A} 7 \% \mathrm{D} 8 \% \mathrm{~B} 6 \% \mathrm{D} 9 \% 84 \% \mathrm{DB} \% 8 \mathrm{C}$.

Katouzian, Homa (1992). The Political Economy of Modern Iran: Despotism and Pseudo-Modernism, 1926-1979. Basingstoke: Macmillan.

Khamenei.ir (2006). Eblágh-e szijászathá-je ráhbordi va beszjár mohemm-e nizám dar-báre-je band-e "dzs" aszl-e csehel-o-csehár Kánun-e aszászi [A rendszer stratégiai és nagyon fontos politikáinak közlése az Alkotmány 44. cikkének c) pontjával kapcsolatban]. A letöltés ideje: 2021. augusztus 16. https://farsi.khamenei.ir/news-content?id=1400.

Khameni, Ali (2005). 20 Year National Vision. Iran Data Porlal. A letöltés ideje: 2021. augusztus 12. https://irandataportal.svr.edu/20-vearnational-vision.

Kordbaccse, Mohamed. (2010-2011). Barávard-e Sáheszháje Andáze je Doulat. [Becslés az állam méretének mutatóihoz] In Nili, Maszúd. 


\section{Külïgyi Szemle}

(szerk.), Doulat va Rusd-e Eqteszádi dar Irán [Állam és gazdasági növekedés Iránban] (5-26. o.).

Lenze, Franz (2008). Der Nativist Galal-e Al-e Ahmad und die Verwesllichung Irans im 20. Jahrhunderl: Eine Analyse der ethnographischen Monographien Awrazan. Tat-nešinha-ye boluk-e Zahra und Ğazire-ye Harg, dorr-e yalim-e halig unler besonderer Berücksichligung seiner Programmschrifi Garbzadegı. Berlin: Klaus Schwarz. A letöltés ideje: 2021. augusztus 12. https://menadoc.bibliothek.uni-halle.de/urn/ urn:nbn:de:gbv:3:5-6213.

Madzslesz-e Surá-je Eszlámi (2017). Iran (Islamic Republic of): Law on the Sixth Five-Year Economic, Cultural and Social Development Plan for 1396-1400. The Asian and Pacific Energy Forum. A letöltés ideje 2021. augusztus 16. https://policy.asiapacificenergy.org/node/3671.

Majd, Mohammad G. (1987). Land Reform Policies in Iran. American Journal of Agricultural Economics, 69(4), 843-848.

Majlis.ir (1955). Qánun-e Bankdári [Banktörvény]. A letöltés ideje: 2021. augusztus 16. https://rc.majlis.ir/fa/law/show/94735\#law categories.

Majlis.ir (1972). Qánun-e Bánki va Puli Kesvar [Az ország monetáris és banki joga]. A letöltés ideje: 2021. augusztus 16. https://rc.majlis.ir/fa/ law/show/96842.

Majlis.ir (1979a). Lájehá-je Qánuni Edáre-je Omur-e Bánkhá [Banki igazgatási törvényjavaslat]. A letöltés ideje: 2021. augusztus 16. https:// rc.majlis.ir/fa/law/show/98287.

Majlis.ir (1979b). Qánun-e Hafádat va Tusza-je Szanáje Irán [Iráni iparvédelmi és fejlesztési törvény]. A letöltés ideje: 2021. augusztus 16. https://rc.majlis.ir/fa/law/show/98153.

Majlis.ir (1979c). Qánun-e Melli sodan-e Bánkhá [Törvény a bankok államosításáról]. A letöltés ideje: 2021. augusztus 16. https://rc.majlis.ir/ fa/law/show/98129.

Majlis.ir (1983). Qánun-e 'amaliját-e Bánki bidun-e Ribá (bahara) [A kamatmentes banki tevékenységről szóló törvény (kamat)]. A letöltés ideje: 2021. augusztus 16. https://rc.majlis.ir/fa/law/show/90388.

Majlis.ir (2000). Qánun-e barnáme-je sevom-e tósze-ye eqteszádi, idzstimáji, va farhangí-ye Dzsumhúri-je Iszlámi-je Írán [Az Iráni Iszlám Köztársaság harmadik gazdasági, társadalmi és kulturális fejlesztési tervének törvénye]. A letöltés ideje: 2021. augusztus 16. https://rc.majlis. ir/fa/law/show/93301. 
N.I.O.C. (2018). A Look at the National Iranian Oil Company's Report in 2018. A letöltés ideje: 2021. augusztus 16. https:/www.nioc.ir/portal/ file/?321174/NIOC-En.pdf.

N. Rózsa Erzsébet (2021). A Közel-Kelet nukleáris kérdései - középpontban az iráni nukleáris program. Külügyi Szemle, 20(3), 145-170.

Nili, Maszúd (szerk.) (2010-2011). Doulat va Rosd-e Eqteszádi dar Irán [Állam és gazdasági növekedés Iránban]. Teherán: Nasr-e Nej.

Nili, Maszúd. és Dargáhi, Haszan (2010-2011). Fa'álijathá-je Doulat va Rosd-e Eqteszádi-je Irán [Az állam tevékenysége és gazdasági növekedés Iránban]. In Nili, Maszúd (szerk.), Doulat va Rosd-e Eqteszádi dar Irán [Állam és gazdasági növekedés Iránban] (249-287. o.).

Presidency of the I.R.I. Plan and Budgel Organization (2021). Iran Statistical Yearbook 2017-2018 (1396). A letöltés ideje: 2021. augusztus 12. https://www.amar.org.ir/english/Iran-Statistical-Yearbook/StatisticalYearbook-2017-2018.

Rahmánzáde Heravi, Mohammed (2019). Negáhi be Eqleszá-e Szijászi-je Irán, az Dahe-je 1340 lá Szál-e 1395. Teherán: Nasr-e Akhtarán.

Rostow, Walt Whitman (1991). The Stages of Economic Growth: A Non Communisı Manifesto. Cambridge: Cambridge University Press.

Sahamyab.com (2020). Sina Bank Shareholders. A letöltés ideje: 2021. április 16. https://www.sahamvab.com/.

Sharifi, Hadi (2014). Cserá Zsápon-e Eszlámi nasodim? [Miért nem lettünk az iszlám Japán?]. Alef. A letöltés ideje: 2021. augusztus 12. http://old.alef. ir/vdcbw5b5arhb50p.uiur.html?222684.

Statisla (2021). Anteil des Finanzsektors an der Bruttowertschöpfung Deutschlands von 2005 bis 2020. A letöltés ideje: 2021. augusztus 16. https://de.statista.com/statistik/daten/studie/309545/umfrage/anteildes-finanzsektors-am-deutschen-bip/.

Slatislical Center of Iranian (2021). Key Figures. A letöltés ideje: 2021. augusztus 12. https://www.amar.org.ir $\%$ D $8 \% \mathrm{AE} \% \mathrm{D} 8 \% \mathrm{A7} \% \mathrm{D} 9 \% 86 \% \mathrm{D} 9$ $\% 87 / \% \mathrm{D} 8 \% \mathrm{~B} 4 \% \mathrm{D} 8 \% \mathrm{~A} 7 \% \mathrm{D} 8 \% \mathrm{AE} \% \mathrm{D} 8 \% \mathrm{~B} 5-\% \mathrm{D} 9 \% 87 \% \mathrm{D} 8 \% \mathrm{~A} \% \mathrm{DB} \% 8 \mathrm{C}-$ $\% \mathrm{DA} \% \mathrm{~A} 9 \% \mathrm{D} 9 \% 84 \% \mathrm{DB} \% 8 \mathrm{C} \% \mathrm{D} 8 \% \mathrm{AF} \% \mathrm{DB} \% 8 \mathrm{C}$.

Surá-je Eszlámi (2008). Qánun-e Edzsrá-je Szijászat-há-je Kulli Aszl-e Csehel va csahárom-e Qánun-e Aszászi [Általános politika-végrehajtási törvény az Alkotmány 44. cikkének bekezdéséről]. A letöltés ideje: 2021. augusztus 16. https://www.mcls.gov.ir/fa/law/260. 


\section{Külïgyi Szemle}

Szálkai Kinga és Szabó Miklós (2021). Az iráni vízválság a klímaváltozás és a növekvő társadalmi elégedetlenség árnyékában. Külügyi Szemle, 2O(3), 5-37.

Tehran Times (2019). Industry Ministry Takes Steps to Reform Auto Sector. A letöltés ideje: 2021. augusztus 16. https://www.tehrantimes.com/ news/439872/Industry-ministry-takes-steps-to-reform-auto-sector.

The World Bank (2021a) GDP Growth (Annual \%) - Iran, Islamic Rep. A letöltés ideje: 2021. augusztus 15. https://data.worldbank.org/indicator/ NY.GDP.MKTP.KD.ZG?locations=IR.

The World Bank (2021b). Overview. A letöltés ideje: 2021. augusztus 15. https://www.worldbank.org/en/country/iran/overview.

The World Bank (2021c). Iran's Economic Update - April 2021. A letöltés ideje: 2021. augusztus 12. https://www.worldbank.org/en/country/iran/ publication/economic-update-april-2021.

Theodora.com (2020). United Arab Emirates Economy 2020. A letöltés ideje: 2021. augusztus 12. https://theodora.com/wfbcurrent/united arab_emirates/united_arab_emirates_economy.html.

Uniled Nations Development Programme (2020). Iran (Islamic Republic of). A letöltés ideje: 2021. augusztus 16. http:/hdr.undp.org/en/countries/ profiles/IRN. 